\title{
Earthquake sequences and seismicity of the Watsonville Region of Central California
}

\author{
A. UDÍAs (*) \\ Ricevuto il 3 Giugno 1969
}

\begin{abstract}
Sumary. - The Watsonville area designates here the region of Central California between the latitude $36^{\circ} 40^{\prime}$ and $37^{\circ} 05^{\prime} \mathrm{N}$ and the longitudes $121^{\circ} 25^{\prime}$ and $121^{\circ} 50^{\prime} \mathrm{W}$. This area can be considered as a regional seismic unit. The seismic activity during the years $1960-1966$ grives a background level of 2 or 3 earthquake of magnitude $2<M \gtrless 3$, per month, with periods of increased activity associated with the occurrence of larger shocks. The presence and nature of sequences of earthquakes in the area is investigated for the period 1952-1966. Three sequences in 1963 are studied in more detail. Tentatively the sequences of the area are grouped in three general types.
\end{abstract}

Riassunto. - Con la denominazione di area di Watsonville si intende qui la regione della California situata tra i $36^{\circ} 40^{\prime}$ e $37^{\circ} 05^{\prime}$ latitudine $N$ ed i $121025^{\prime}$ e $121^{\circ} 50^{\prime}$ longituline $W$. Tale area può essere considerata come unità sismica regionale. Negli anni 1960-1966, l'attività sismica of re un quadro di 2 o 3 terrenoti di magnitudo $2<M<3$, al mese, con periodi di più intensa attività associata al verificarsi di scosse più anpie. Viene studiata la presenza e la natura dei fenomeni sismici nellarea predetta durante il periodo 1952-1966, e si fa un esame più particolareggiato di tre periodi sismici avvenuti nel 1963. A titolo di prova si sono raggruppati in tre tipi generali, i periodi sismici osservati nella stessa area.

\section{INTRODUCTION.}

The Watsonville region designates here the area between the latitudes $36^{\circ} 40^{\prime}$ and $37^{\circ} 05^{\prime}$ and the longitudes $121^{\circ} 25^{\prime}$ and $121^{\circ} 50^{\prime}$. Spain.

(*) Instituto Geografico y Catastral, Servicio de Sismologia - Madrid, 
This area covers a section of the San Andreas fault and is ideally suited for a detailed study of regional seismic conditions because it is covered by a net of permanent and mobile stations operated by the University of (alifornia. The geology of the area is of rather complex nature as shown in Figure 1 (Jennings and Strand, 1958).

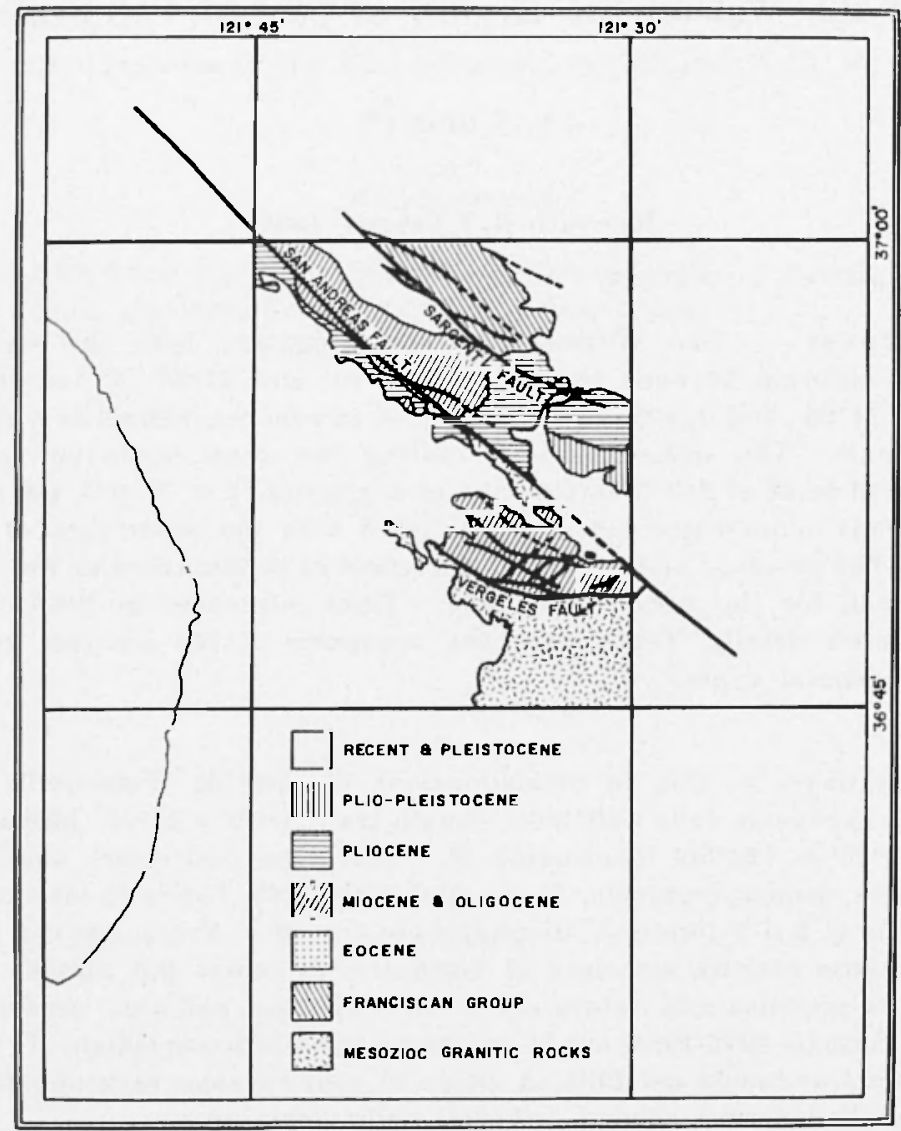

Fig. 1 - Generalized geological map of the Watsonville area (after .J. B. Allen).

The main geological feature is the San Andreas fault which crosses the area striking $\mathrm{N}+7^{\circ} \mathrm{W}$. Most of the area to the West of the fault is covered with alluvial deposite and Pleistocene non-marine sediments. Northeast of the fault the sediments are Oligocene and Miocene marine sediments. This part is traversed by a series of faults which trend 
parallel to the San Andreas of which the Sargent fault is the most important. The northern part of the granitic mass forming the Gabilan Range is at the southeastern end of the area, to the southwest of the San Andreas fault. $\Lambda$ t the north edge of the granitic outerop there is a series of criss-crossing faults oftshooting from the San Andreas in northwest and southwest directions.

\section{Location of Permanent and Mobile Seismographic Stations.}

In the region under study, there is a concentration of recording stations. Besides the permanent stations of Vineyard (VIT), Santa Cruz (SCC), Mount Familton (MHC), Llanada (LLA), and Paraiso

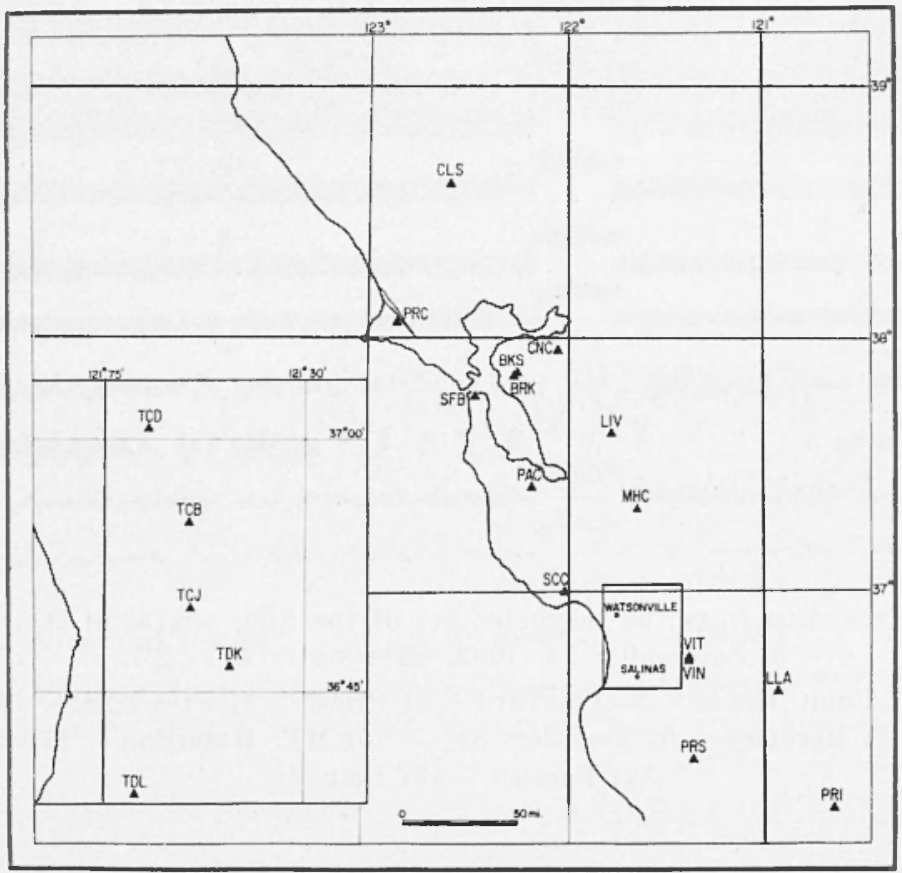

Fig. 2 - Map of Northern California showing the locations of permanent and mobile seismographic stations operated by the University of California.

(PRS), which surround the area, three mobile stations were used, since 1963, during the time following the main shocks and placed in the immediate area. Figure 2 shows the location of the permanent 
stations and some of the sites where the mobile units were installed. 'These stations are part of the telemeter net opereted by the University of California. They are equipped with short-period vertical Benioff

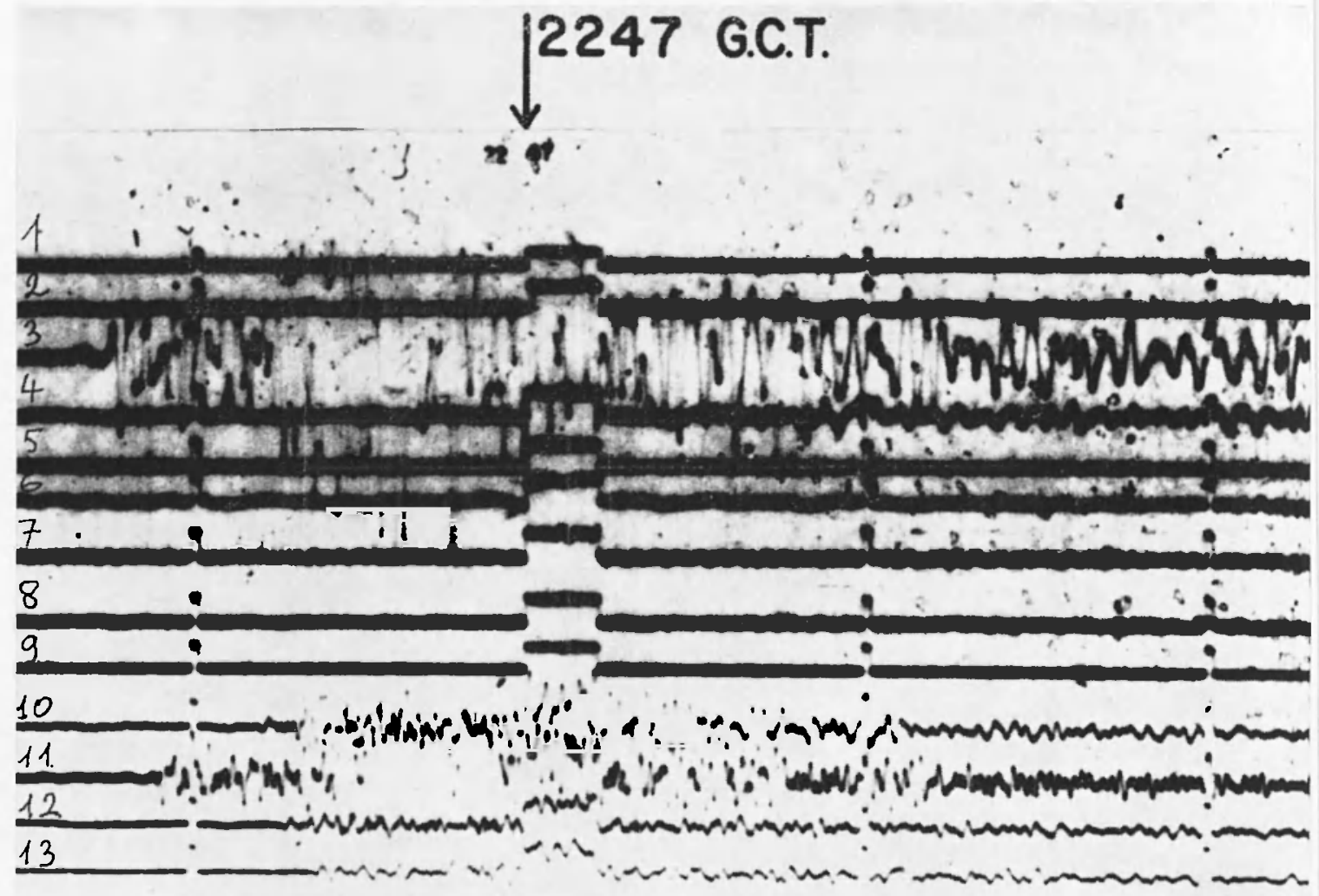

Figr. 3 - Recording from the telemeter net of the first arrival of the aftershock of September 14, 1963, $22^{n}+6^{m}+1 \mathrm{~s}, \quad K=2.5$.

1) Radio - 2) Point Reyes - 3) Vineyard - 4) Priest - 5) Priest SII - 6) Calistoga

7) Concord - 8) Berkeley - 9) Berkeley s.I - 10) IIT. ILamilon - 11) Santa (ruz 12) Paraiso - 13) Llanada.

seismographs. The signals are telemetered and recorded at Berkeley. The peak magnification of the instruments ranges from 100,000 to 200,000 at a period of about 0.3 seconds. Examples of the recording for the aftershock of September 14,$1963 ; 22^{\mathrm{n}} 46^{\mathrm{m}}$, are in Figure 3 . Each mobile station is also equipped with a vertical short-period Benioff seismograph. The instruments were run at a peak magnification ranging from 15,000 to 40,000 . 
EARTIQLAKR SLQLENCES ANW FISUTCITY OF THE WATSONVILLE, ETC. 119

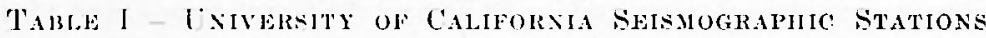
IN OPERATION 1963.

Station

Symbol
Latitude North longiturle

West
Elevation (meters)

P'ermanent ślalions

\begin{tabular}{|c|c|}
\hline AlR ${ }^{\prime}$ & Areala \\
\hline B R R & Berlieley (llavilamol) \\
\hline B Kis & Berkeley (Byerly) \\
\hline Cls & Calistogra \\
\hline CNO & Comeord \\
\hline FRl: & Fresuo \\
\hline 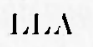 & Laanada \\
\hline $11110^{\circ}$ & MIt. IIantilton \\
\hline $\operatorname{MN}$ & Mineral \\
\hline$P A C$ & Palo Allo \\
\hline I'RC' $^{\prime}$ & Point Reyes \\
\hline PRI & Priest \\
\hline P'RS & Paraiso \\
\hline sco! & Santa Cruz \\
\hline $\mathrm{SH}$ & San Franciseo \\
\hline SIIs & Shansta \\
\hline VIN & Vineyard (local) \\
\hline 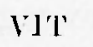 & Vincyard (telemeter) \\
\hline
\end{tabular}

$40^{\circ}+2.6^{\prime} \quad 124^{\circ} 04.5^{\prime} \mid 5 !$

$37^{\circ} 52.4^{\prime} \quad 122^{\circ} 15.6^{\prime} \quad 81$

\begin{tabular}{ll|l}
$37^{\circ} 52.6^{\prime}$ & $122^{\circ} 14.1^{\prime}$ & 276
\end{tabular}

$\begin{array}{lll}38^{\circ} 38.2^{\prime} & 122035.1^{\prime} & 457\end{array}$

\begin{tabular}{l|l|l}
$37^{\circ} 58.1^{\prime}$ & $122^{\circ}\left(04.3^{\prime}\right.$ & 36
\end{tabular}

$\begin{array}{lll}36^{\circ}+6.0^{\prime} & 119^{\circ} 47.8^{\prime} & 88\end{array}$

\begin{tabular}{l|l|l}
$36^{\circ} 37.0^{\prime}$ & $120^{\circ} 56.6^{\prime}$ & 475
\end{tabular}

\begin{tabular}{l|l|l}
$37^{0} 20.5^{\prime}$ & $121^{\circ} 38.5^{\prime}$ & 1282
\end{tabular}

\begin{tabular}{l|l|l}
$40020.7^{\prime}$ & $121^{\circ} 36.3^{\prime}$ & 1495
\end{tabular}

\begin{tabular}{|l|l|l}
$37^{\circ} 25.0^{\prime}$ & $122^{\circ} 10.9^{\prime}$ & 83
\end{tabular}

$38^{\circ} 04.8^{\prime} \quad 1222^{\circ} 2.0^{\prime} \quad 404$

\begin{tabular}{l|l|l}
$36^{\circ} 08.5^{\prime}$ & $120^{\circ} 39.9^{\prime}$ & 1187
\end{tabular}

\begin{tabular}{l|l|l}
$36^{\circ} 19.9^{\prime}$ & $121^{\circ} 22.2^{\prime}$ & 363
\end{tabular}

$\begin{array}{llll}37^{\circ} 000.4^{\prime} & 121^{\circ} 59.8^{\prime} & 128\end{array}$

$\begin{array}{lll}37^{\circ} 46.6^{\prime} & 122027.1^{\prime} & \text { 100 }\end{array}$

$40^{\circ} 41.6^{\prime} \quad 122023.5^{\prime} \quad 312$

$366^{\circ}+5.0^{\prime} \quad 121023.1^{\prime} \quad 330$

\begin{tabular}{l|l|l}
$36^{\circ}+5.0^{\prime}$ & $121^{\circ} 23.3^{\prime}$ & 380
\end{tabular}

\section{Mobile Unil Stations}

\begin{tabular}{|c|c|}
\hline $\mathrm{T} C \mathrm{C} B$ & C'hamberlain \\
\hline TCl & Mt. Madomua \\
\hline C J & Dorney \\
\hline$D$ & Sugrarloaf \\
\hline 1 & Merrill \\
\hline
\end{tabular}

\begin{tabular}{l|l|r}
$36^{\circ} 55.9^{\prime}$ & $121^{\circ} 39.4^{\prime}$ & 240 \\
$37^{\circ} 00.7^{\prime}$ & $121^{\circ} 42.3^{\prime}$ & 564 \\
$36^{\circ} 50.1^{\prime}$ & $111^{\circ} 38.7^{\prime}$ & 207 \\
$36^{\circ} 46.5^{\prime}$ & $121^{\circ} 35.7^{\prime}$ & 79 \\
$36^{\circ} 37.9^{\prime}$ & $121^{\circ} 42.9^{\prime}$ & 18
\end{tabular}


The truck sites designated as TCB and TCJ were occupied through the period corresponding to the May 1963 sequence. The locations TCJ, TIJ and TDK were used during the time covering most of the August and September, 1963 sequences. The coordinates of the permanent and mobile stations are given in Table $I$. The mobile station at Dorney ( $\mathrm{TCJ}$ ) which occupies the central part of the area was kept in continual operation from September 1 to October 25 (except for September 6), of 1963 providing and excellent coverage of the activity in the area. The station was kept in operation until the activity had returned to the normal level in order to check on the frequency of occurrence of small earthquakes.

\section{Comptateness of a Set of Eartheuakes.}

Darthquakes are events that can be specified by five parameters, $x, y, z, t, E\left(^{3}\right)$. The parameters $x, y, z$ specify the spatial location of the focus of the earthquake; $x, y$ refer to the latitude and longitude of the epicenter and $z$ to the depth of focus; $t$ specifies the origin time and $E$ the energy released as elastic waves. This last parameter can be interchanged with $M$, the magnitude, as defined in the conventional manner. An earthquake, thus considered, constitutes a point in a five-dimensional space $(x, y, z, t, E)$.

$A$ helpful concept in the study of seismicity is that of a complete set of earthquakes. We mean by a complete set of earthquakes a set containing every earthquake that occurred within given boundaries of the five parameters already specified. The boundaries on $x, y$, and $z$ depend on the region under study. The boundaries on $t$ specify the period of time which is covered by the analysis. The boundaries on $E$ (or $M$ ) are a function of the sensitivity and coverage of the recording stations in the region and period of time under consideration. The lower limit must be quantitatively determined from the actual distribution of stations in the area so that all earthquakes above this lower limit are recorded. This idea is of special interest in discussions dealing with the frequency of occurrence of small earthquakes.

The boundaries for the set of earthquakes in this study are the following:

$x$ between $36^{\circ} 40^{\prime}$ and $37^{\circ} 05^{\prime}$
$y$ between $121^{\circ} 25^{\prime}$ and $121^{\circ} 50^{\prime}$
$z \quad$ less than $20 \mathrm{~km}$.


The limit on $z$ is based on the depth found for all the earthquakes of this area for which there is sufficient information.

The limits on $M$ depend on the period of time under study. For the time intervals when only the permanent stations of the telemeter net were in operation the lower magnitude for which an earthquake could be located in this region is of the order of $M=2.2$. For the time intervals when the mobile stations were in operation the lower limit can be reasonably set to $M=1.0$. This applies, for example, to the periods May 7 to 17 , and $A$ ugust 31 to October $25,1963 . \Lambda$ higher limit on $y$ than that given by the sensitivity of the operating stations can be arbitrarily selected depending on the magnitude level of the seismic activity in which one is interested.

This concept of the completeness of a set of earthquakes is of particular importance when studying the frequency of occurrence of earthquakes with time and magnitude. Analyses of earthquake sequences have sometimes been made when there is no certainty that the actual number of earthquakes with given magnitude is the same as the number of recorded earthquakes with that magnitude. In our analysis a lower limit of magnitude is always assigned above which the recorded earthquakes form a complete set.

Shismicity of THe W WTSONVIJLA REgIon, 1960-1966.

The seismicity activity of the region has been studied during the seven years period from 1960 to 1966 . This period has been divided into two, the first including the years 1960 to 1963 , and the second from 1964 to 1966 .

\section{SEISMicity 1960-1963.}

For this interval the seismic activity of the region above the 2.5 magnitude level has been studied. Above this magnitude level, the earthquakes in this region and period of time constitute a complete set.

The linear plots of frequency and magnitude versus time for the whole period are given in Figure $4 . \Lambda$ number of significant features are noticeable:

(a) There is a continuous activity of about two to three earthquakes of magnitudes between 2.5 and 3.5 per month. 
(b) There is a fair correlation between the peaks of the frequency plot and those of the magnitude.

(c) For every earthquake of magnitude greater than 4.0 there is a corresponding peak in the frequency plot.

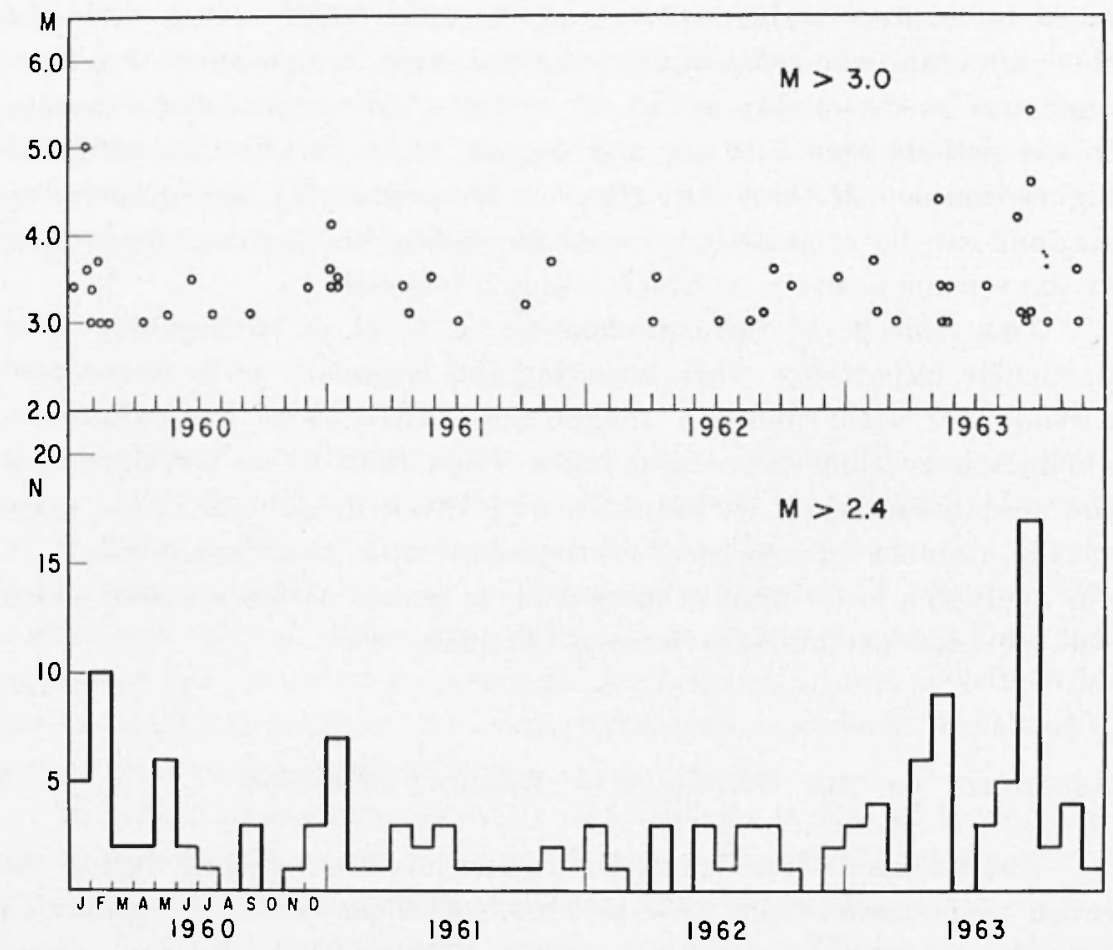

Tig. 4 - Magnitude and frequency versus time for earthquakes in the Watsonville region during the period 1960 to 1963 inclusive.

These features seem to indicate that for this region and time interval, earthquakes of magnitude 4 and above did not occur singly, but as part of a sequence, either a classical aftershock sequence or a swarm of earthquakes. The four most prominent peaks in the frequency plot correspond to the occurrence of the earthquakes of January 20, 1960; January 4, 1961; May 7 , August 31, and September 14,1963 . The entire period shows a continuous level of background activity of 2 to 3 earthquakes of magnitude between 2.5 and 3.5. per month. The region was at this level of activity from January 1961 to February 1963. 
To combine the information given in the plot of frequency and magnitude versus time, the energy of the earthquakes which occurred in one month was summed and its logarithm multiplied by $N$, the number of earthquakes. The quantity $F$, defined as

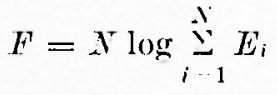

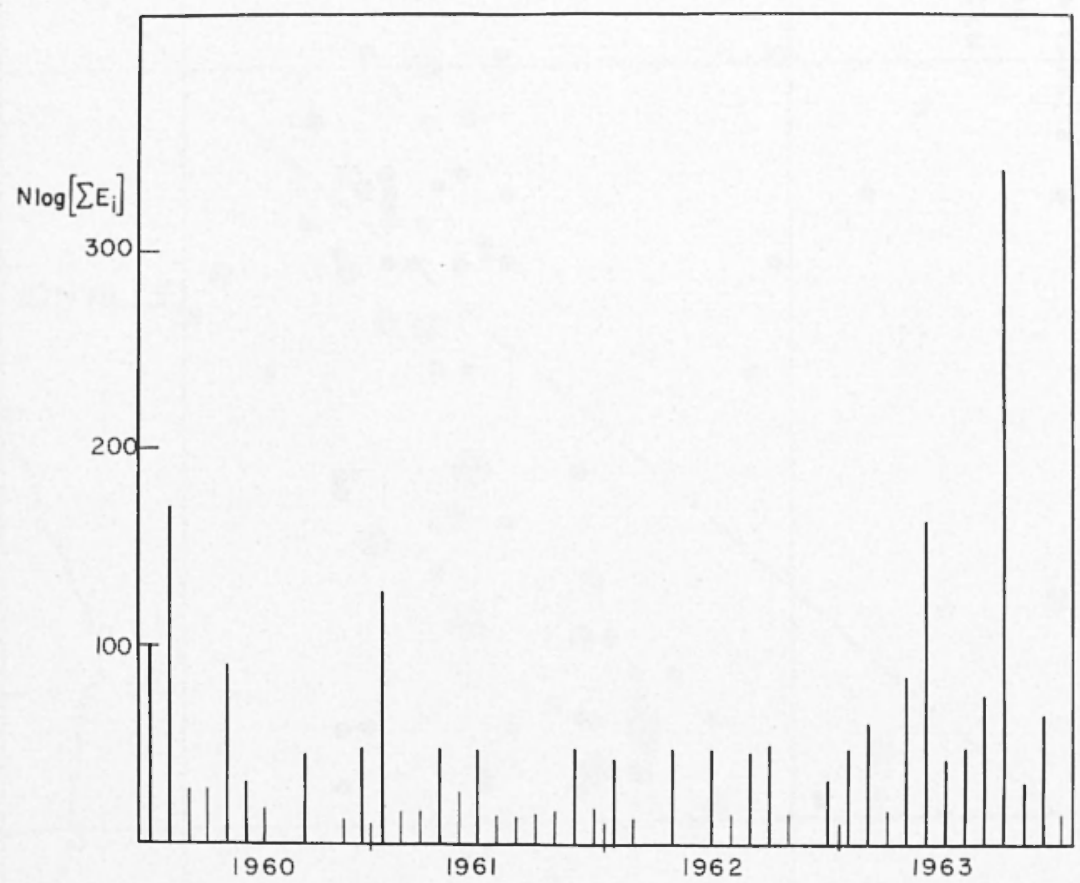

Figr. 5 - Plot of $X \log \sum_{i=1}^{N} E_{i}$ versus time. for the period 1960-1963.

has been plotted in Figure 5 for this period. This kind of plot, although it has no direct physical interpretation, serves to emphasize the occurrence of large number of earthquakes per unit time connected with the occurrence of a large earthquake. The plot also gives a grood representation of the background seismic activity. The large peak at September 1963 is due to the already mentioned occurrence of the two sequences.

This discussion has been carried out for earthquakes of magnitude greater than 2.5. The relation between frequency and magnitude for smaller earthquakes has been studied for 1963 . In this year, because 


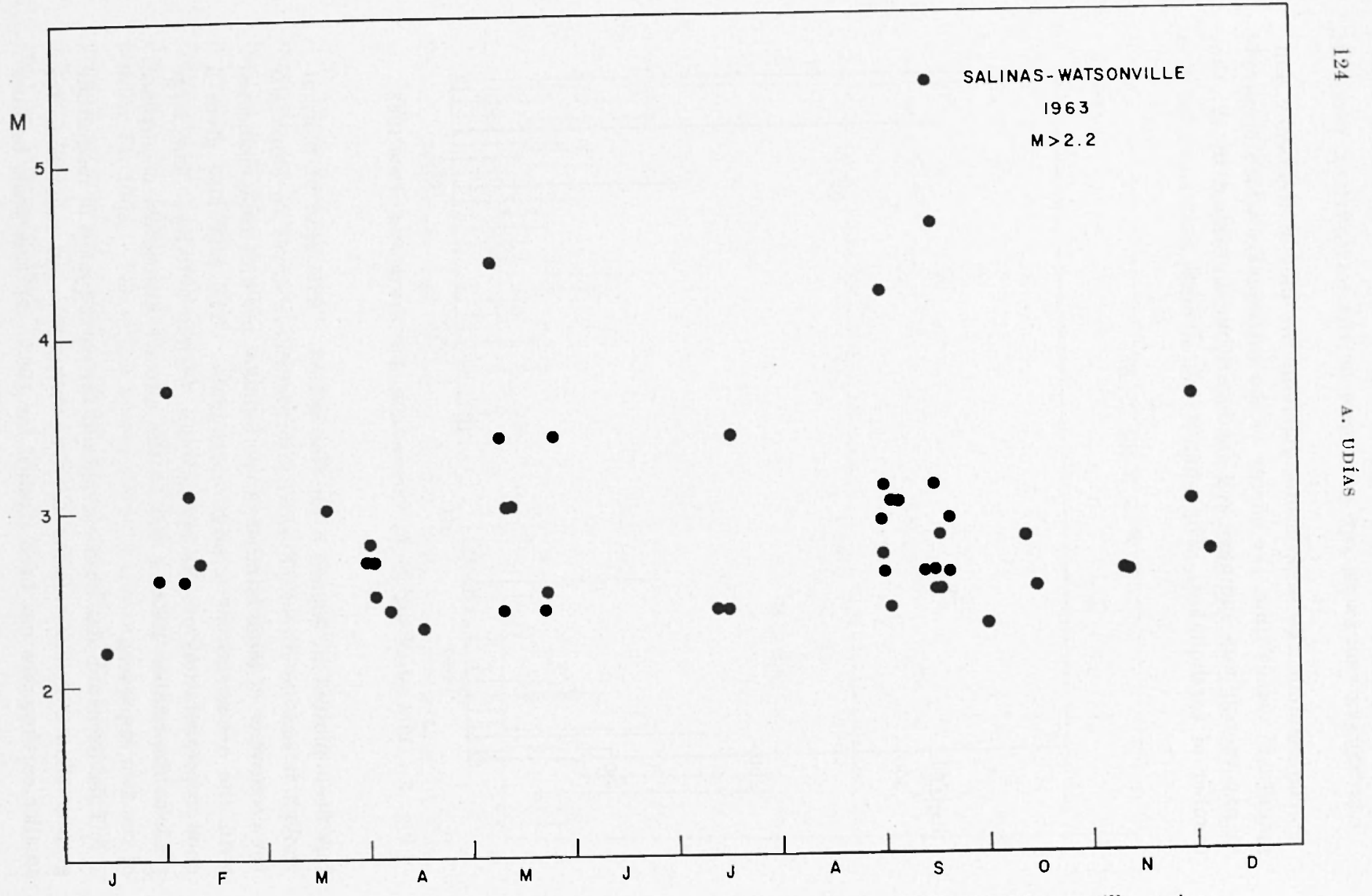

Fig. 6 - Plot of magnitude versus time during the year 1963 for $M \geqslant 2.2$, in the Watsonville region. 
EARTHQUAKE SEQUENCES AND SEISMICITY OF THE WATSONVILE, ETC. 125

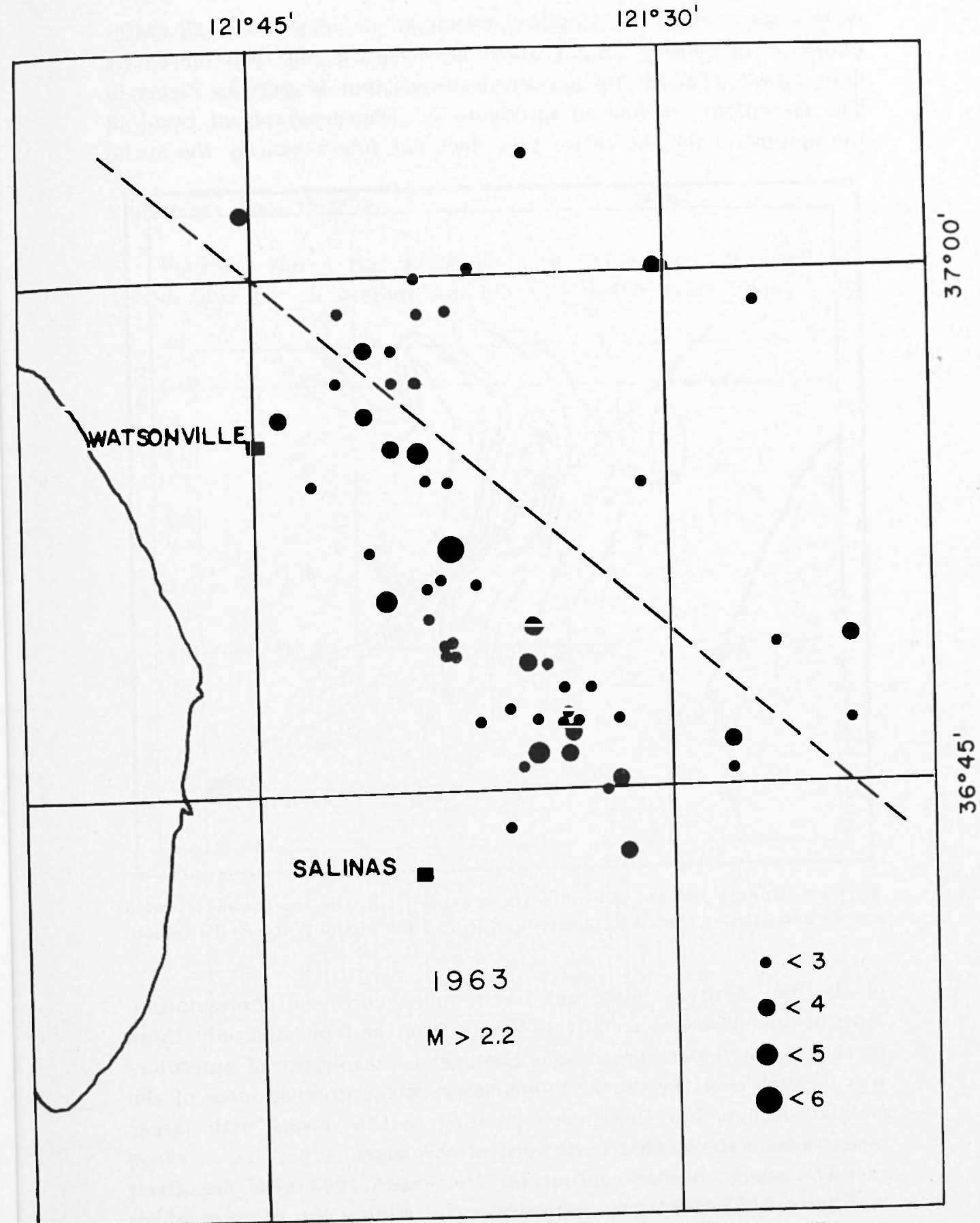

Fig. 7 - Epicenter location of the earthquakes in the Watsonville area during 1963. $M \geqslant 2.2$. The number refer to magnitude. 
of the operation of the Berkeley telemeter net of stations, all earthquakes of magnitude 2.2 and above are recorded and their epicenters determined. The plot of magnitude versus time is given in Figure 6. The apicenters are plotted in Figure $i$. The geographical trend of the epicenters for the entire year does not follow exactly the strike

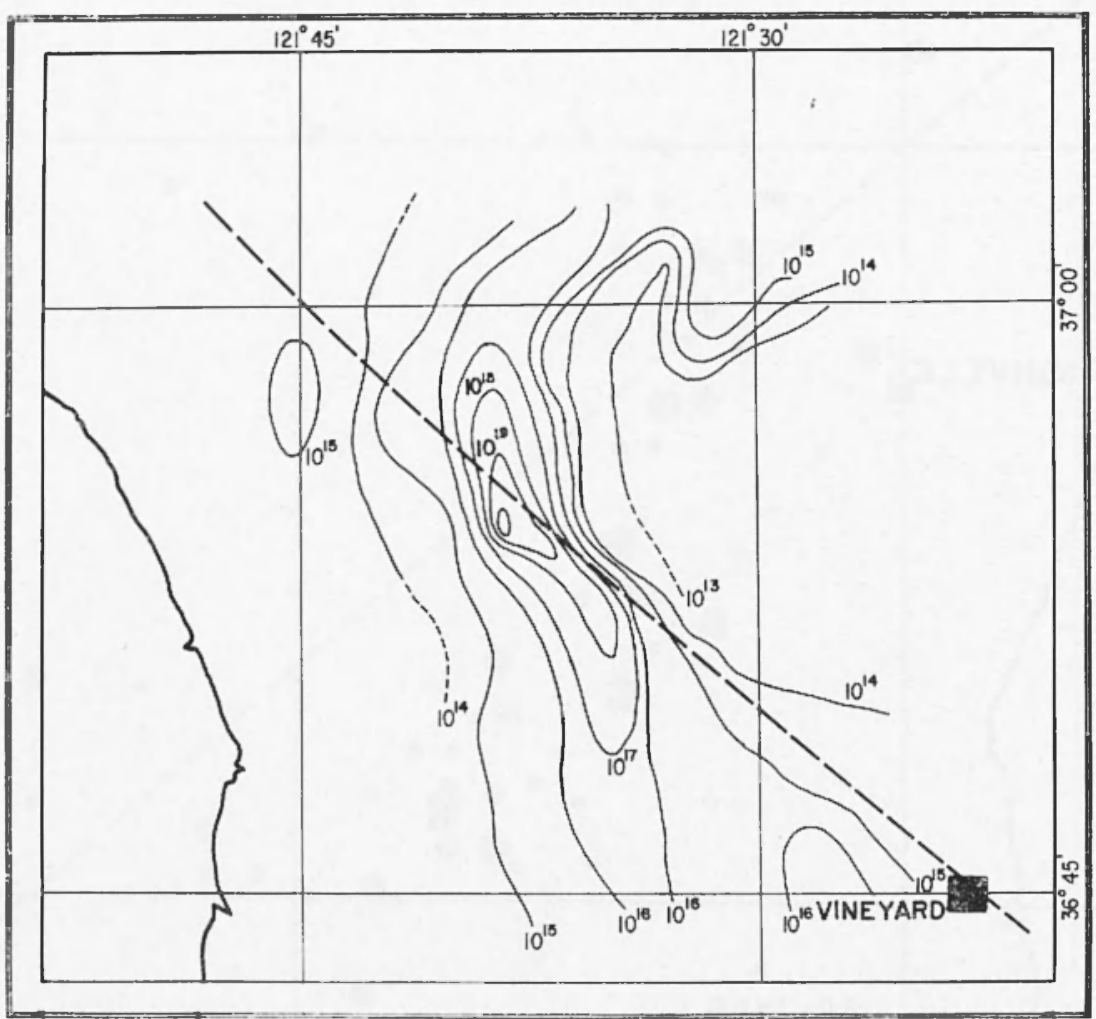

Fig. 8 - Energy release contours (in ergs) for all the earthquakes with magnitule greater than 2.2 , oceurring during 1963 in the Watsonville region.

of the San Andreas fault, but has a more north-south orientation. Most of the epicenters are at the West side of the fault, and only those of the northern part are in the East side. $A$ number of epicenters was located near the northern boundary of the granitic mass of the Gabilan Range, but those corresponding to the shocks with larger magnitudes were located northward of this mass.

The energy-release contour for the entire 1963 year are given in Figure 8. The contours were drawn by adding the energies of all 
shocks located within a square of $5 \mathrm{~km}$ side. The contomr lines emphasize the trend of the epieenters. This trend, as mentioned before. does not coincide with the strike of the San Andreas, but makes an angle of about $20^{\circ}$ with the trace of the fault.

\section{SEISMICI'Y $196+1966$.}

Figure 9 shows the linear plots of magnitude and frequency versus time for all earthquakes above a given magnitude. Three

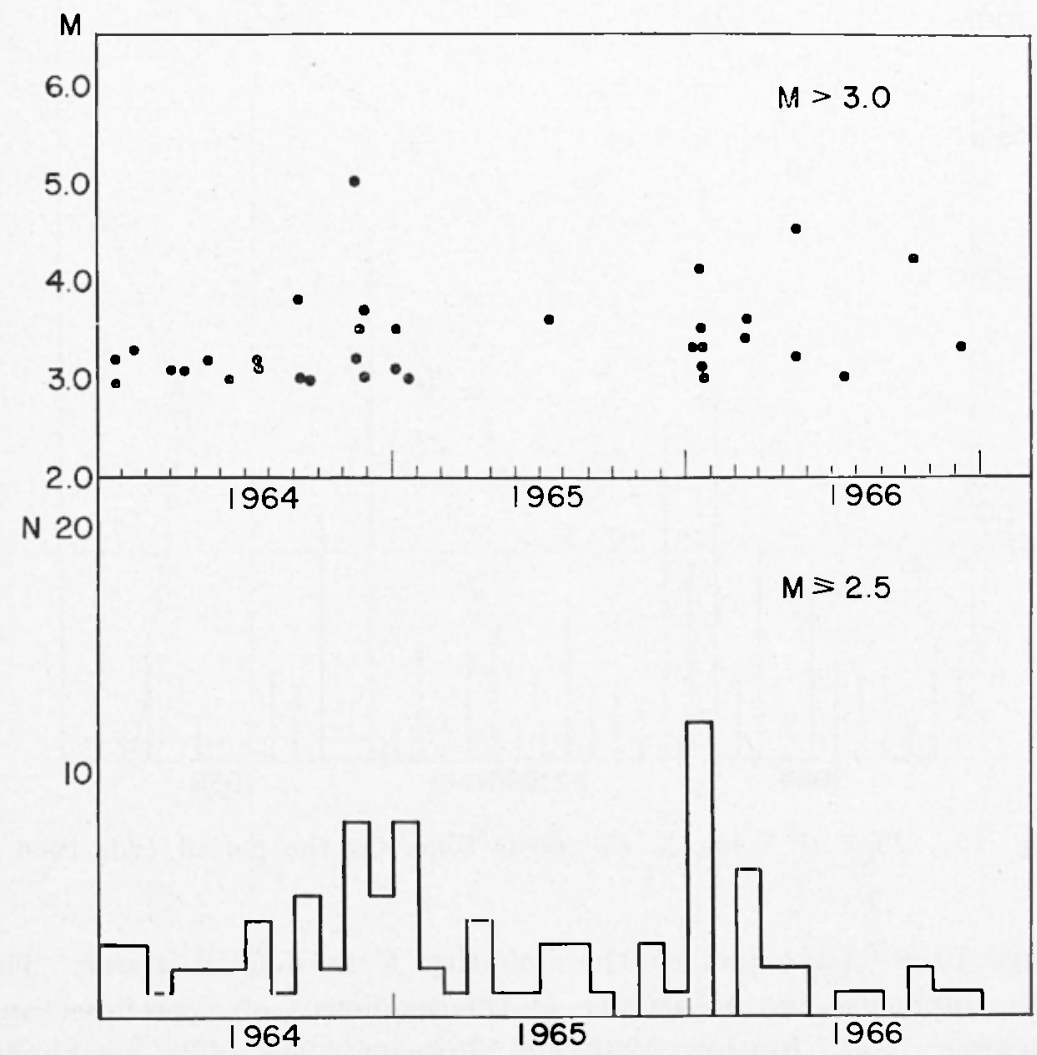

Figr. 9 - Magnitude and frequency versus time for earthquakes in the Watsonville region during the period 1964-1966.

peaks in the frequency plot correspond to aftershocks related to main shocks of $M$ greater than 4.0 in November $196 t$ and January 1966; and to a main shock with $y=3.5$ in January 1965. There are two 
shocks with magnitude 4.5 and 4.2 which were not followed by any increase in the seismic activity at least at the level of $M \geqslant 2.5$, level at which our analysis was made. If these shocks were followed by aftershocks must have been all of very small magnitude, and less than 2.5. During 1965 the seismic activity was at a low level. In

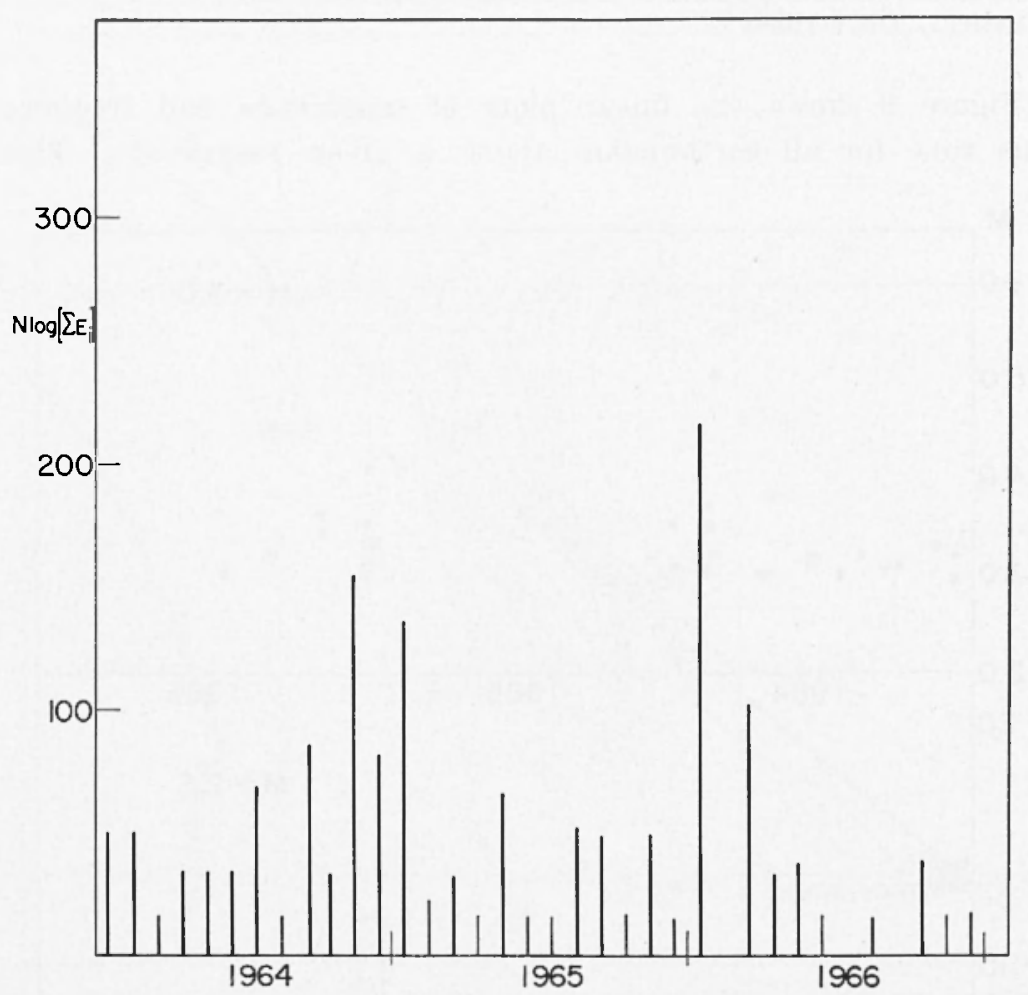

Fig. 10 - Plot of $N \log \sum_{i=1}^{N} E_{i}$ versus time, for the periol $1964-1966$.

Figure 10 we have plotted the quantity $F$ as defined above. The peaks emphasize the occurrence of the sequences of September and November 1964, January 1965 and January 1966. The peak corresponding to March 1966 does not correspond to a sequence in the usual sense, but to an increase of activity during a ten days period from March 7 to 16 , and located in the central area around $36^{\circ} 48^{\prime}$, $121^{035}$. Outside these periods, the level of the background seismic activity for the area is of 1 to 3 earthquakes above $M=2.5$ per month. This agrees with the results from the precedent period. 
Figure 11 shows the location of the epicenters $(M>2.5)$ for the three years. Comparing with the location of the epicenters of 1963 (Fig. 7) we notice the same concentration of epicenters southwest

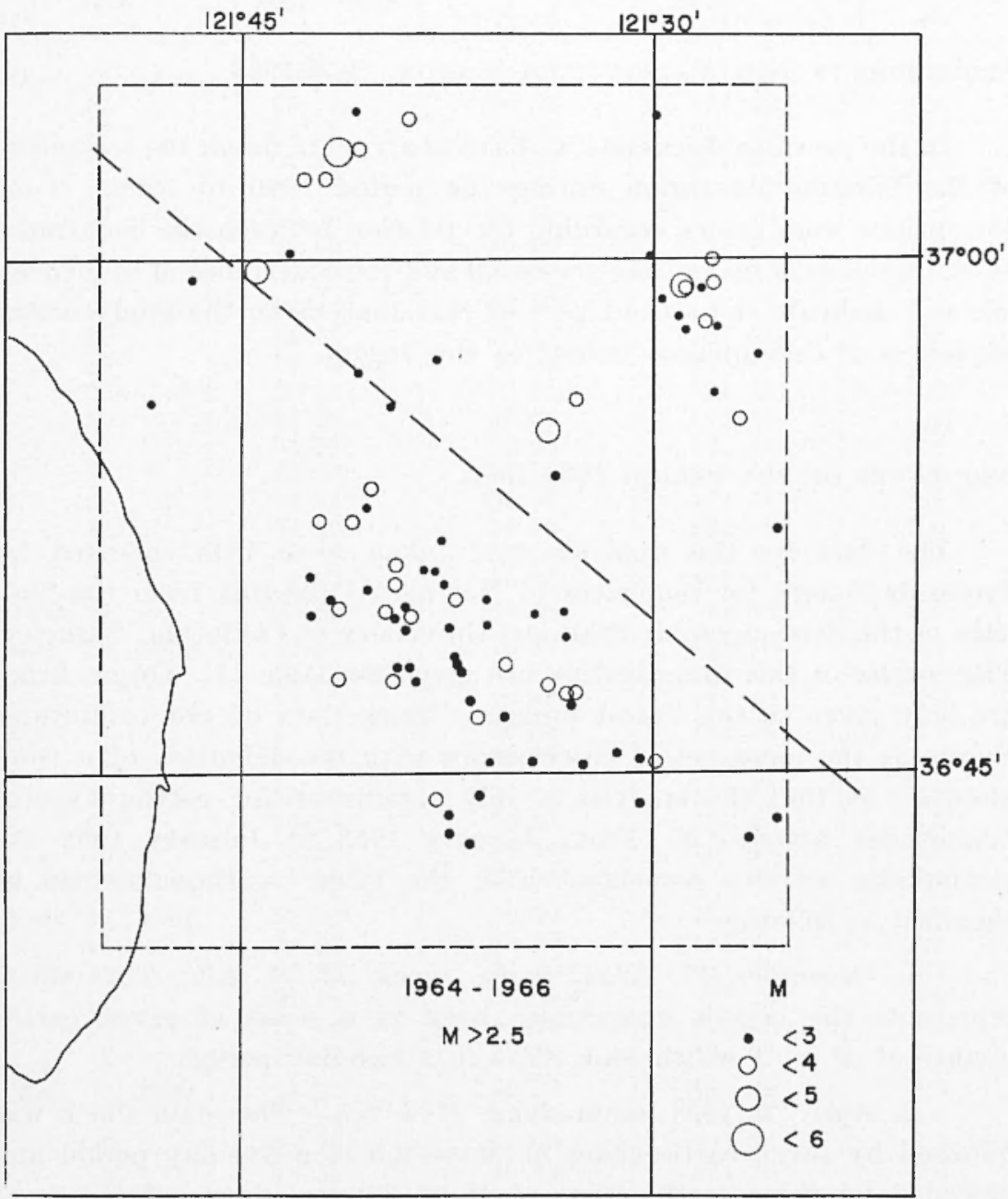

Fig. 11 - Epicenter location of the earthquakes in the Watsonville region during the period $1965-1966$.

of the San Indreas fault in the central part of the region. Besides, there are two clusters of epicenters corresponding to the sequences of November 1964 (Corralitos series) and January 1966 (San Felipe Lake series) in the northeast side of the fault. Outside the shocks related 
to these two series almost all the other earthquakes occurred in the area southwest of the San Andreas, with the exception of the two shocks with $M>4.0$ occurred in 1966 and not followed by any series.

Sequences in the Watronvilla Region, 1953-1966.

In the previous discussion we have analysed in detail the seismicity of the Watsonville region during the period 1960 to 1966. Some conchusions were drawn regarding the relation between the occurrence of earthquakes of magnitude above t.o and the occurrence of sequences. We will dedicate the second part of this analysis to the study of the sequences of earthquakes located in this region.

ShQ UeNCES OF THE PERIOD 1953-1962.

The data for this analysis were taken from lists collected by Professor Byerly for sequences in Northern California from the Bulletin of the Seismographic Stations, University of California, Berkeley. The results of this investigation are given in Table II. Origin times are only given to the closest minute. These data do not conform as closely as the more recent observations with the definition of a complete set so that the analysis is only significant for earthquakes of magnitudes above 3.0. From January 1953 to January 1963 the earthquake activity associated with the larger earthquakes can be classified as follows:

1. December 17, 1953, main shock $M=4.2$. This shock represents the largest magnitude shock in a series of seven earthquakes of $M>3$ which took place in a two-day period.

2. April 25, 1954, main shock $M=5.3$. The main shock was followed by seven earthquakes of $M>2.5$ in a five-day period and preceded by three earthquakes of $M>3.0$ two days before.

3. December 1, 1956, main shock $M=4.4$. No appreciable increase recorded in the occurrence of earthquakes immediately before or after.

4. June 26, 1957 and Tecember 10-12, 1957. Two swarms of earthquakes of magnitude between 2.0 and 3.5 , not commected with any shock of greater magnitude. 
Table 11 - Series of eartilquakes in tire Watsonyille drea DURING THE PERIOL 1950-1961.

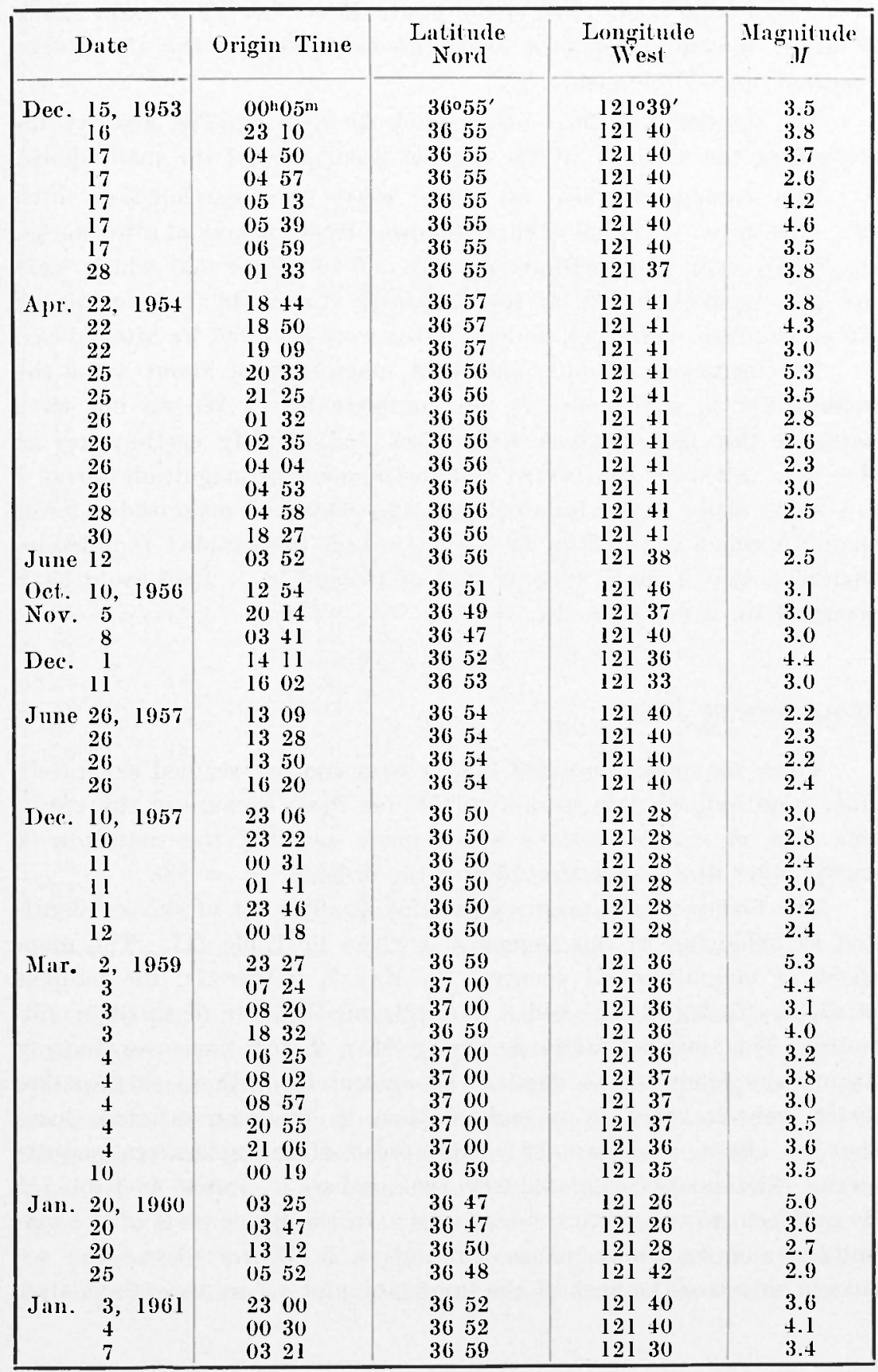


5. March 2, 1959, main shock $M=5.3$. The main shock was followed by nine earthquakes $M>3.0$ in a two-day period.

6. Jannary 20, 1960, main shock $M=5.0$. The main shock occurred outside the defined area, and only some of the aftershocks occurred inside the area.

7. January 3, 1961, main shock $M=4.1$. The activity increased at the 2.0 level at the time of occurrence of the main shock.

The conclusions are: (a) there were four eurthquakes with $M>5.0$ in ten years, all of them followed by sequences of aftershocks. (b) There were five earthquakes with $4.0<M<5.0$ which were not associated with any of the sequences started by the magnitude 5.0 earthquakes; of these, at least three were followed by aftershocks.

The argument about a threshold magnitude of about 4 for the main shock in a sequence is not complete here. We do not have data for this period which will detect and identify earthquakes at the $M=2.0$ level and below, and earthquakes of magnitude about 4 are more likely to be followed by aftershocks of magnitudes lower than 3.0 which is the limit of the magnitude detectable. It is likely, therefore, that a shock such as that of December, 1, 1956 could have occurred in a sequence.

SEquences of 1963.

Three sequences occurred in this year and are studied sepurately since more refined data were available for them because of the use in this time of mobile stations which made possible the detection of earthquakes down to magnitudes of the order of $M=1.0$.

The first sequence occurred on May 7. The list of shocks identified as belonging to this sequence is given in Table III. The main shock of magnitude 4.4 occurred on May $7,07 \mathrm{~h} 07 \mathrm{~m} 47^{\mathrm{s}}$; the number of shocks during May 7 and 8 is small and they are of small magnitudes. This number inreases during May 9 and decreases sharply during the following 10 days. The epicenters of those earthquakes which were recorded by enough stations to allow an accurate location are shown in Figure 12. The spread of the epicenters is quite large. The shocks designated with the numbers 18 and 35 in Table III do not seem to belong to the sequence. In the linear plots of the magnitude and frequency versus time, given in Figure 13, we can see that in this case the peak of the frequency plot occurs three days after 
EARTIQUAKE SEQUENCES AND SEISMICITY OF TIF WATSONVILLe, ETC. 133

Table 111 - Eartiquakes from MaY 7 to MaY 22,1963 FOR THE WATSONVILLE REGION.

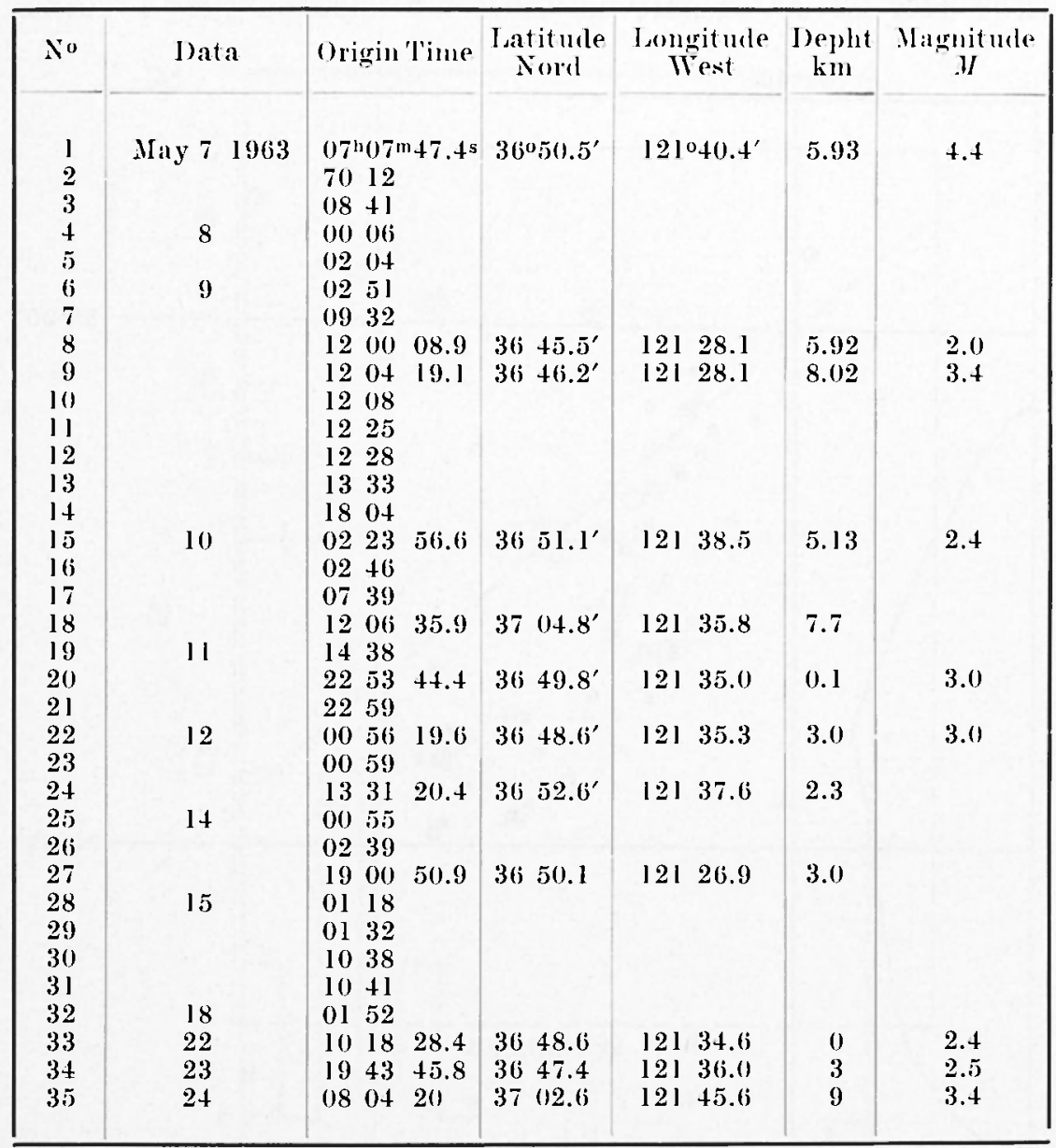

the main shock. The connection of the shocks on May 9 with the main shock of May 7 is not very clear. The shape of the plots is quite different from the classical pattern of aftershocks sequences such as that found for the sequences of September, 1963. This sequence, although it was started by the occurrence of the earthquake of magnitude 4.4 on May 7 , does not conform exactly to this pattern mainly because of the absence of activity later on May $\tau$ and on Nay 8 .

The other two sequences followed earthquakes occurred on August 31 and September 14 ; they were previously studied by the author $\left({ }^{12}\right)$. 
The list of the earthquakes from August 31 to October 1 is given in Table IV. Only those earthquakes were located for which sufficient data for an accurate epicenter determination were available.

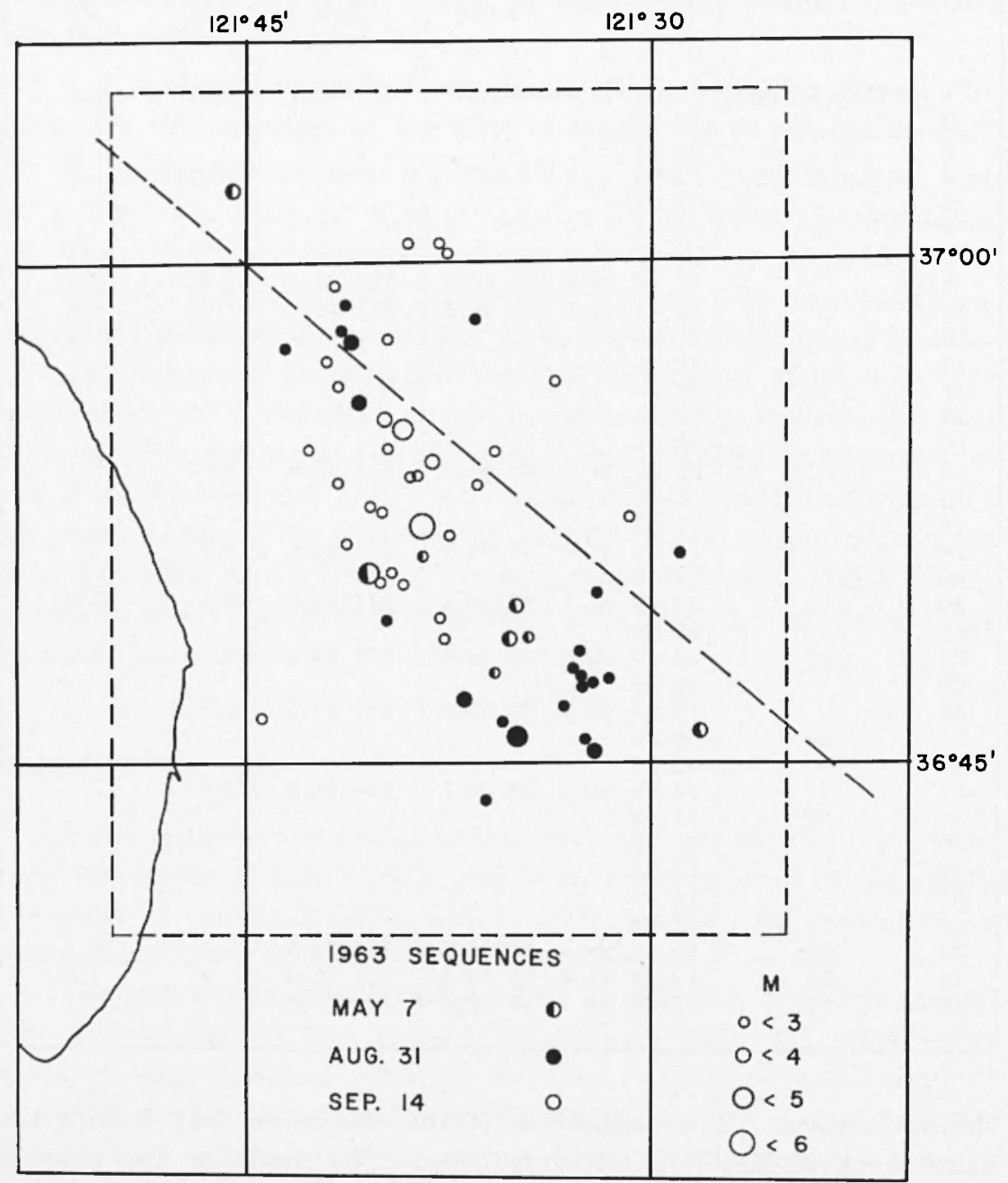

Fig. 12 - Adopted location of the earthquakes of the May 7, August 31 and September 14, 1963 sequences.

The epicenters and depth of these shocks were found using a special program $\left(^{2}\right)$ for a high-speed computer. The epicenters are believed to be accurate within about $2 \mathrm{~km}$. Calculated estimates for the depth of the focus are in general less accurate. 
The magnitudes were found from the recordings of the WoodAnderson instruments at BRK, PAC, VIN, and MIHC (cf. Table I). For earthquakes with magnitude smaller than 2.0, the magnitudes

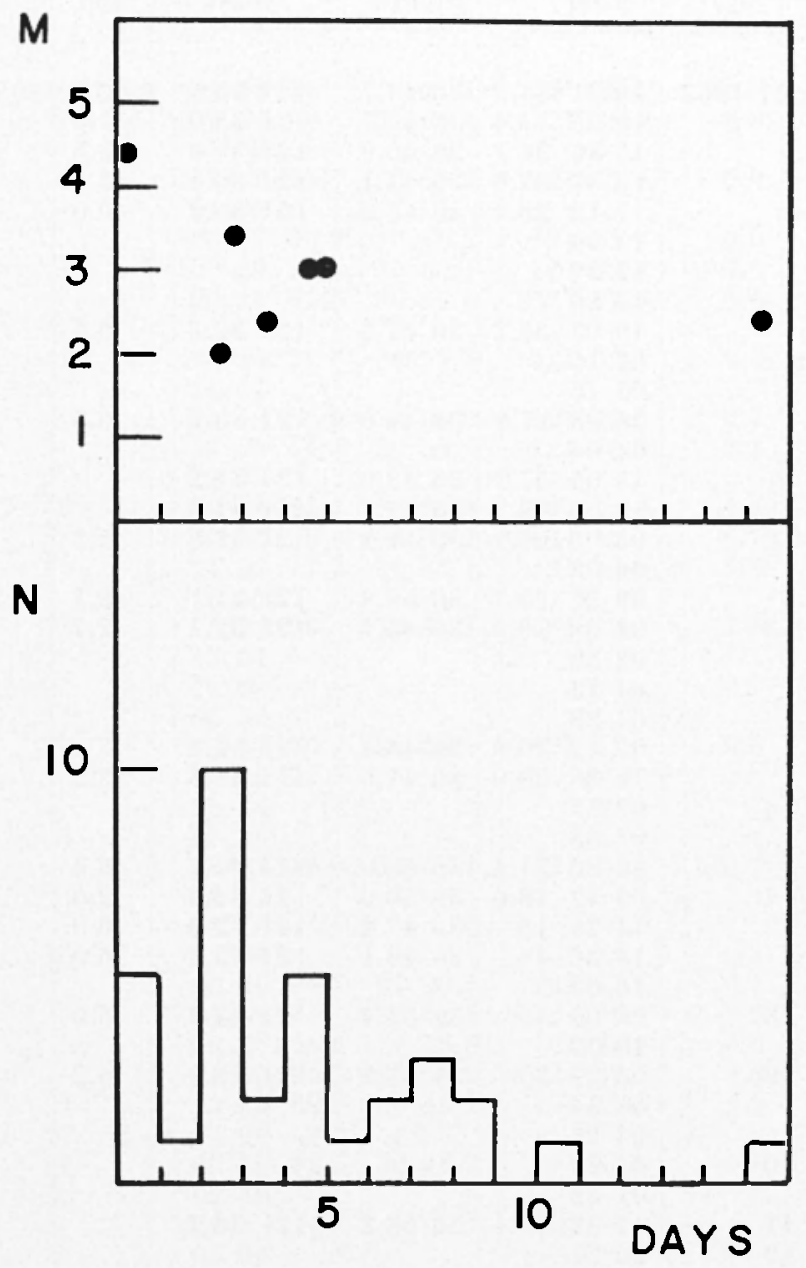

Fig. 13 - Magnitude and frequency versus time for the May 7,1963 sequence.

were calculated from the maximum trace amplitude recorded by the Beniofi instrument at TCJ (Dorney). In this calculation the amplitudes were reduced to the hypothetical response of a Wood-Anderson instrument with the same location. 
'TABIE IV - EARTHQUAKES FroN August 3I to OCtorer I, I963 IN THE Watsonvihe REgion.

\begin{tabular}{|c|c|c|c|c|c|c|c|}
\hline No & Date & Origin & Time & $\begin{array}{c}\text { Latiturle } \\
\text { Norrl }\end{array}$ & $\begin{array}{l}\text { Longiturle } \\
\text { West: }\end{array}$ & $\begin{array}{l}\text { Depth } \\
\text { kim }\end{array}$ & $\underset{I I}{\text { Magrnitude }}$ \\
\hline 1 & Augr.3I |963 & $16^{\mathrm{h}} 31^{\mathrm{n}}$ & $\mathrm{n} 14.2^{\mathrm{s}}$ & $36^{\circ}+5.7^{\prime}$ & $12 \mid 335.0^{\prime}$ & 2.3 & 4.2 \\
\hline 2 & & 1635 & 17.0 & $36+7.7$ & 12133.0 & 1.6 & 2.6 \\
\hline 3 & & 1635 & 34.1 & $36+6.9$ & 12137.0 & 3.5 & 3.0 \\
\hline+ & & 1637 & 07.6 & $36+4.1$ & 12136.4 & 3.7 & 2.7 \\
\hline 5 & & $17 \quad 12$ & 26.7 & 3645.8 & 12135.2 & 0.0 & 2.7 \\
\hline 6 & & 1734 & & & & & 1.2 \\
\hline 7 & & 1737 & & & & & 2.0 \\
\hline 8 & & 1738 & & & & & 1.3 \\
\hline 9 & & 1907 & 36.2 & $36+7.3$ & 12132.3 & 6.5 & 2.4 \\
\hline 10 & Sept. I & $02 \quad 15$ & & & & & 1.3 \\
\hline $\begin{array}{l}11 \\
12\end{array}$ & & & & & & & $\begin{array}{l}1.4 \\
2.1\end{array}$ \\
\hline $\begin{array}{l}12 \\
13\end{array}$ & & $\begin{array}{l}0403 \\
04 \quad 04\end{array}$ & 17.8 & $36+6.6$ & 12133.2 & 0.5 & $\begin{array}{l}2.1 \\
0.6\end{array}$ \\
\hline 14 & & 1505 & 57.1 & 3657.9 & $121+1.2$ & & 2.0 \\
\hline 15 & & 1505 & 59.2 & 3657.7 & $121+1.0$ & & 3.0 \\
\hline 16 & 2 & 0505 & 06.9 & $36+8.2$ & 12132.8 & 5.3 & 2.0 \\
\hline 17 & & 0608 & & & & & 0.9 \\
\hline 18 & & 0956 & 33.7 & 3658.8 & $121+1.1$ & 2.1 & 2.0 \\
\hline 19 & 3 & 0108 & 16.9 & 3645.1 & 12132.1 & 2.7 & 3.0 \\
\hline 20) & & 0259 & & & & & 0.8 \\
\hline 21 & & $04 \quad 13$ & & & & & 0.9 \\
\hline 22 & & $0+29$ & & & & & 0.6 \\
\hline 23 & & $07+2$ & 19.9 & 3645.4 & 12132.4 & 3.9 & 2.4 \\
\hline 24 & & 16338 & 28.0 & $36+7.5$ & 12131.6 & 3.2 & 2.0 \\
\hline 25 & 4 & 0317 & & & & & 1.0 \\
\hline 26 & & 0753 & & & & & 0.6 \\
\hline 27 & & 1026 & 31.4 & 3655.9 & $121+0.7$ & 6.3 & 3.0 \\
\hline 28 & 7 & (0) 42 & 18.0 & 3650.0 & 12132.0 & 2.0 & 2.0 \\
\hline 29 & & $1+28$ & 15 & $36+7.2$ & 12132.3 & 6.0 & 1.6 \\
\hline 30 & & $1+36$ & 48 & 3649.1 & 12139.8 & 6.0 & 1.6 \\
\hline 31 & & 1603 & & & & & 1.0 \\
\hline 32 & 8 & 0605 & 45 & 3657.4 & 12143.6 & 5.0 & 2.0 \\
\hline 33 & & 1003 & & & & & 0.6 \\
\hline 34 & 9 & 0639 & 30 & 3651.2 & 12128,9 & 5.2 & 1.8 \\
\hline 35 & & 0654 & & & & & 1.0 \\
\hline 36 & & 0725 & & & & & 1.6 \\
\hline 37 & 10 & 0) 23 & & & & & 1.0 \\
\hline 38 & & 0) 32 & & & & & 0.8 \\
\hline 39 & 11 & 1733 & 50.4 & 3658.2 & 12136.3 & & 1.6 \\
\hline 40 & 12 & 2027 & & & & & 1.2 \\
\hline+1 & 13 & 0051 & & & & & 1.2 \\
\hline 42 & & 1305 & 35.2 & $36+7.2$ & 12132.4 & 1.2 & 2.6 \\
\hline 43 & & 2246 & & & & & 1.4 \\
\hline $4+$ & 14 & (1) 54 & & & & & 1.5 \\
\hline 45 & & 1946 & 17.0 & 3652.0 & 12138.3 & 3.3 & 5.4 \\
\hline 46 & & 19) 58 & 40.9 & 3655.1 & 12139.9 & 2.8 & 3.1 \\
\hline 47 & & 2028 & 11.2 & 3655.0 & 12139.3 & 12.4 & 4.6 \\
\hline 48 & & 2246 & +1 & 3654.0 & 12138.0 & 7.0 & 2.5 \\
\hline 49 & 15 & (1)0 17 & 51 & 3653.5 & 12138.9 & 4.0 & 1.9 \\
\hline 50 & & (1)0 34 & 35.2 & $\begin{array}{ll}36 & 52.5\end{array}$ & 12139.9 & 15.6 & 1.8 \\
\hline
\end{tabular}


Table IV (conlinualion)

\begin{tabular}{|c|c|c|c|c|c|c|c|}
\hline $\mathrm{So}^{\prime \prime}$ & loate & Oriris & Time & $\begin{array}{l}\text { Latituale } \\
\text { Noral }\end{array}$ & $\begin{array}{c}\text { Longitule } \\
\text { West }\end{array}$ & $\begin{array}{l}\text { Depth } \\
\text { kint }\end{array}$ & $\underset{\text { MII }}{\text { Magnit ule }}$ \\
\hline 51 & \multirow[t]{14}{*}{ Sept I5 I963 } & \multicolumn{2}{|c|}{$01^{\mathrm{h}}+6^{\mathrm{m}}[0 \mathrm{~s}$} & $366^{\prime} 54.3^{\prime}$ & $121042.6^{\prime}$ & 2.4 & 2.4 \\
\hline 52 & & 0234 & 37 & 3700.4 & 12138.9 & (6.0) & 2.3 \\
\hline 53 & & 0309 & & & & & 1.3 \\
\hline 54 & & 0349 & 54.7 & 3651.5 & $121+1.4$ & 3.9 & 2.5 \\
\hline 55 & & 0426 & & & & & 1.0 \\
\hline 56 & & $05+4$ & 09.2 & 3648.2 & 12133.9 & 0.0 & 2.3 \\
\hline 57 & & 06659 & 22.7 & 3650.1 & 12139.3 & 3.6 & 1.6 \\
\hline 58 & & $09+1$ & 31.5 & 3648.6 & 12137.6 & 4.4 & 2.1 \\
\hline 59 & & I0 21 & & & & & 1.1 \\
\hline (j) & & 1414 & 21.6 & 3653.3 & 12136.1 & (6.0) & 1.8 \\
\hline 61 & & 1555 & & & & & 1.1 \\
\hline 62 & & 1558 & 50.9 & 3650.6 & $12 \mid 39.5$ & 2.7 & 2.6 \\
\hline 63 & & 1708 & 44.3 & 3656.4 & 12133.5 & 2.1 & 2.1 \\
\hline (j4 & & 1723 & & & & & \\
\hline 65 & 16 & (0) & +5.1 & 3657.0 & $121+2.0$ & 4.8 & 2.3 \\
\hline 66 & & (0) 55 & 36.6 & 3657.7 & 12139.7 & 6.5 & 2.8 \\
\hline 67 & & (1) 32 & 11.5 & 3656.1 & $121+1.6$ & 5.9 & 2.0 \\
\hline 68 & & 1055 & & & & & \\
\hline 69 & & 1631 & 32 & 3649.4 & 12137.8 & 7.3 & 1.6 \\
\hline 70 & & 1704 & & & & & 0.9 \\
\hline 71 & & 2109 & & & & & 1.3 \\
\hline 72 & 17 & 0556 & & & & & 0.9 \\
\hline 73 & & $20+1$ & 50 & $36+6.1$ & 12144.5 & 9.8 & 2.0 \\
\hline 74 & & 2239 & & & & & \\
\hline 75 & & $23+5$ & & & & & 1.1 \\
\hline 76 & 18 & 1136 & & & & & 1.6 \\
\hline 77 & & $|25|$ & 46.0 & 3655.4 & 12125.5 & 10.7 & 2.0 \\
\hline 78 & & 2042 & & & & & 0.7 \\
\hline 79 & & 2248 & & & & & 1.4 \\
\hline 80 & 19 & 0215 & & & & & 1.0 \\
\hline 81 & & $0(j 20)$ & 44 & 3700.7 & 12137.8 & 9.1 & 1.6 \\
\hline 82 & & 0958 & ()1 & $36+4.3$ & 12135.7 & 9.2 & 1.6 \\
\hline 83 & & 1216 & 28.3 & 3653.6 & 12138.7 & 4.6 & 2.9 \\
\hline 84 & & 1836 & 05.0 & 3700.2 & 12137.6 & 5.8 & 2.6 \\
\hline 85 & 21 & 1329 & 58.9 & 3659.2 & $121+1.6$ & 8.9 & 2.4 \\
\hline 86 & 22 & 1120 & & & & & 1.5 \\
\hline 87 & 24 & (0) 35 & 42.5 & 3646.7 & 12133.8 & 5.6 & 1.6 \\
\hline 88 & 25 & $02+6$ & & & & & 0.7 \\
\hline 89 & & 02 & & & & & 1.1 \\
\hline 90 & & 0526 & & & & & 1.6 \\
\hline 91 & & 1108 & & & & & \\
\hline 92 & & 1109 & & & & & \\
\hline 93 & & 1117 & 47.9 & $36 \quad 52.7$ & 12140.2 & & 1.9 \\
\hline 94 & 26 & 10 32 & 28.2 & 3663.1 & $121+1.7$ & II.t & 1.9 \\
\hline 95 & & 10 +6 & 05.4 & $365+.3$ & 12139.8 & 4.1 & 2.2 \\
\hline 96 & & 2308 & & & & & 1.3 \\
\hline 97 & 27 & 2353 & 30.8 & 3651.7 & 12137.4 & 4.7 & 2.2 \\
\hline 98 & 30 & 1129 & & & & & 1.3 \\
\hline 99 & Oct. 1 & (1) 728 & 07.3 & $3(; 50.3$ & $121+(0.0$ & 5.6 & 2.0 \\
\hline 100 & & 0847 & 57.6 & 3652.1 & 12130.7 & 9.4 & 2.3 \\
\hline
\end{tabular}


The location of the shocks are given in Figure 12. Some characteristics should be noted:

(a) The earthquakes of the first sequence are concentrated at the south end of the region with a few shocks at the north end. The gaj) between these two groups of the first sequence is filled by the aftershocks of the second sequence.

(b) Abont eighty per cent of the shocks occurred on the west side of the San Andreas fault. The general trend of the earthquakes of both sequences is oriented in a $\mathrm{N} 24^{\circ} \mathrm{W}$ direction. This direction intersect the trend of the fault at an angle of about 23 degrees. Because of the high accuracy in the determination of the epicenters, this trend must be considered as being significant. This trend coincides with the general trend of the epicenters in the region as was seen in the first part of this paper.

(c) The depths of the shocks range from 1 to $12 \mathrm{~km}$, but most of them are between 3 and $6 \mathrm{~km}$. No particular pattern was found in the depths, neither as to the time of occurrence, nor the location in relation to the San Andreas fault.

(d) All shocks with magnitudes over 4.0 lie on a narrow belt oriented in a northwest direction. The energy released decreases as the earthquakes separate from this belt.

A quantity which has been used often in describing the characteristics of earthquake sequences is the gradient of the curve giving the cumulative frequency of occurrence versus magnitude $\left({ }^{10},{ }^{13}\right)$. The curves for the September 14, sequence, and for the entire period August 31 to October 1 , are given in Figure 14. Data have been plotted in increments of magnitude of 0.2 and the shocks of magnitude above 3.0 have not been used. The points are linear between $M-2.0$ and $M=3.0$ and the slopes are $b=0.84$ for the September 14 sequence and $b=0.89$ for the two sequences together. The points between magnitudes 1.0 and 2.0 are also linearly distributed but with a different slope, $b=0.36$. This value is very small and may point to the fact that the control over all shocks in this magnitude range was not as complete as expected, or that the relation between $\log N$ and $M$ is not the same for all magnitude ranges. The inclusion of the largest shock in the series and the sampling interval have, as was pointed out by Ryall et al. $\left({ }^{8}\right)$, a great influence in the determination of $b$. Including the largest shocks the author $\left({ }^{12}\right)$ found separately for the two sequences 


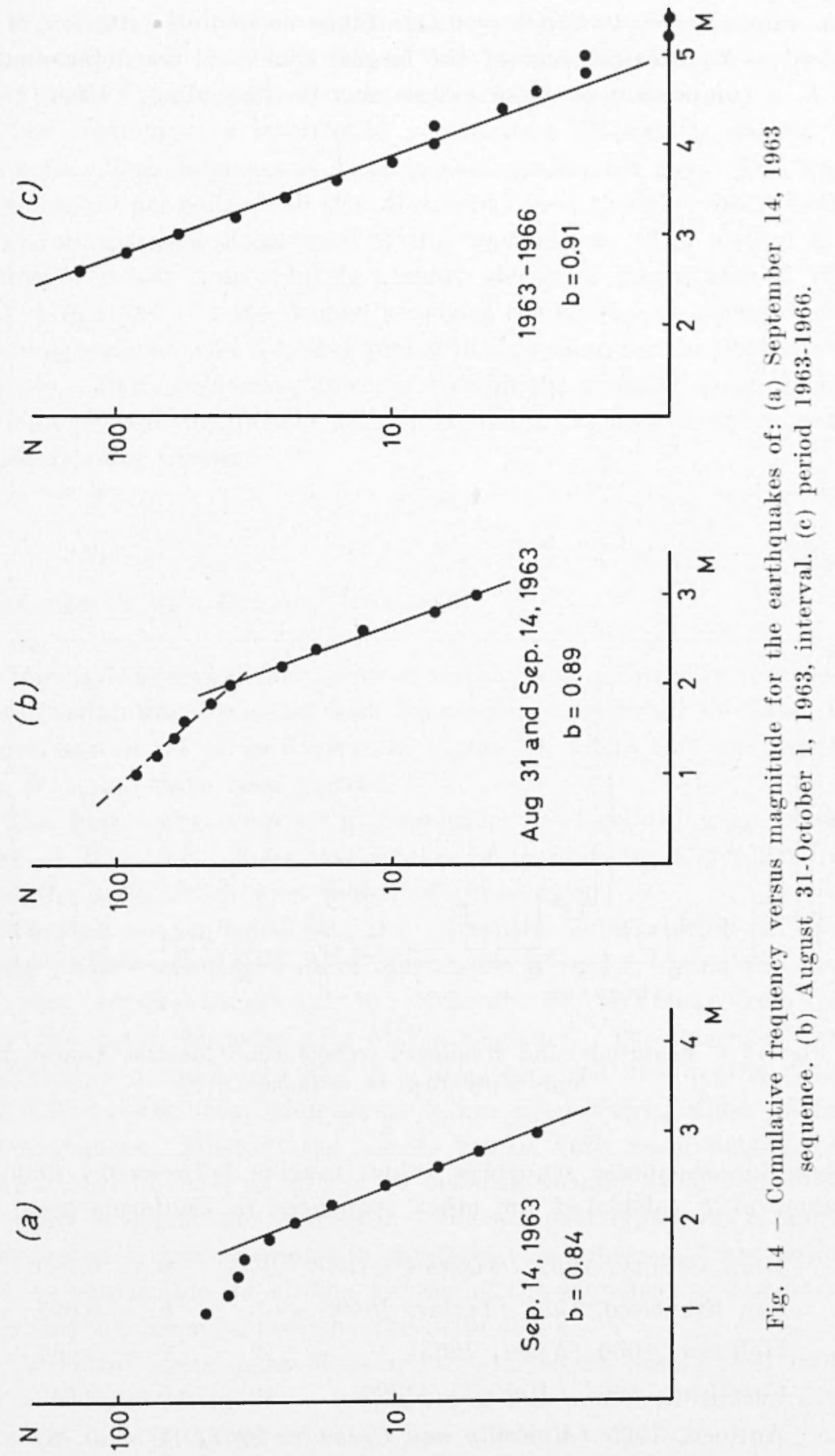


the values $b=0.49$ and $b=0.41$. Since no definite criterion is followed as to the inclusion of the langest shocks in the determination of $b$, a comparison of these values may be misleading. Utisu $\left({ }^{13}\right)$ has

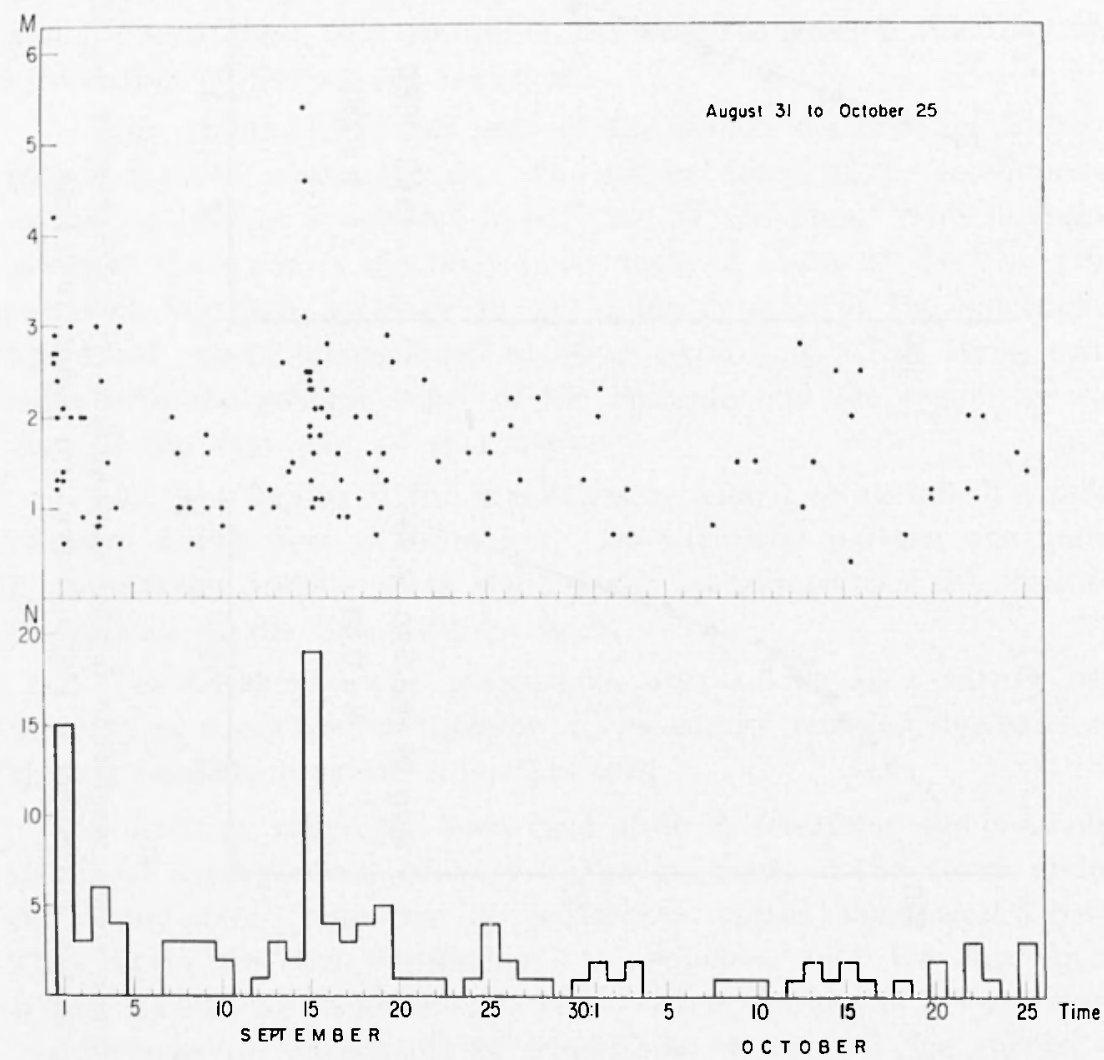

Fig. 15 - Iagnitule and frequency versus time for the August 21 and september 14 sequences.

found for Japaneese sequences values ranging between 0.7 and 0.8 . Values of $b$ calculated for other sequences in California are:

Kern County, 1952 (Oakeshot [elitor], 19:5.) $\quad b=0.789$

San Francisco, 1957 (Tocher, 19.5.9) $\quad b=0.691$

Hollister, 1960 (Niazi, 1963)

$b=0.664$

Corralitos, 1964 (McEvilly, 1966)

$b=0.63$

Antioch, 1965 (McEvilly and Casaday, 196\%) $b=0.78$. 
Figure 14 also shows the frequency-magnitude relation for all earthquakes from 1963 to 1966 in this region, obtaining $b=0.91$ which is the value usually found for Central California.

The frequency of occurrence versus time diagram is shown in Figure 15. The frequency is given in earthquakes per day. For both sequences, 36 per cent of all the aftershocks took place in the 24 -hour period following the occurrence of the main shock. The plot of the mannitude versus time exhibits a sharp decay of magnitude of the shock with time. In the August sequence the shocks with magnitude 3.0 are spread out over a longer period of time than for the September sequence. I3oth sequences, however, exhibit the chassical sharp decay of frequency and magnitude with time which has been found in earlier aftershocks studies.

Sequences of THF PERIOD, 196t-1966.

During this period four series of earthquakes occurred in the area. Data of the shoeks associated with the sequences are given in Table $V$. The location of the series is given in Figure 16, where only the shocks with $M>2.5$ have been plotted.

The first series occurred in September 196.1 following an earthquake of $M=3.8$. Four earthquakes of magnitudes above 2.5 followed the main shock in a period of three days.

The second sequence was the Cormalitos series started on November 1,1964 after a shock of magnitude $M=5.0$. This sequence has been studied in detail by McEvilly ('). We take from his study the main characteristics of the sequence. The epicenters are all located in a smanl area of $4 \mathrm{~km}$ diameter, and the depths range from 9 to $14 \mathrm{~km}$, this being about $7 \mathrm{~km}$ deeper than those of the 1963 sequences. Most of the shocks are of very small magnitude; of the 31 earthquakes of $M>1.0$ between 16 and 24 of November only 6 are of magnitude above 2.0 . The sequence represents a highly concentrated source, a volume in the form of a sphere of $1 \mathrm{~km}$ radius could be responsible for all the focuses of the sequence, and most of the energy has been released by the main shock.

The third series near Watsonville, started on January 1, 1965, with a main shock of $M=3.5$ and was followed by 7 shocks with $M>2.5$ in a 7 day period. 
Tabie V - SERIES OF EARTHQUakes IN THE WATSONVILIE AREA DURING THE PERIOH) 1964-1966.

\begin{tabular}{|c|c|c|c|c|c|}
\hline \multicolumn{2}{|r|}{ Dite } & Origrin Time & \multirow{2}{*}{$\begin{array}{c}\text { Iatitude } \\
\text { Nord } \\
\\
36^{\circ} 52.2^{\prime} \\
52.6 \\
49.7 \\
49.8 \\
49.6\end{array}$} & \multirow{2}{*}{$\begin{array}{l}\text { Jongitude } \\
\text { West } \\
121+1.1 \\
40.4 \\
38.9 \\
38.6 \\
39.7\end{array}$} & \multirow{2}{*}{$\begin{array}{c}\text { Magnitude } \\
. I \\
\\
\\
3.8 \\
2.6 \\
3.0 \\
2.7 \\
3.0\end{array}$} \\
\hline Siept. & $\begin{array}{l}1 \quad 1964 \\
2 \\
3\end{array}$ & $\begin{array}{lll}19^{\mathrm{n}} 49^{\mathrm{m}} & 16.5 \mathrm{~s} \\
19 & 52 & 06.3 \\
22 & 33 & 29.4 \\
01 & 58 & 06.4 \\
13 & 56 & 59.3\end{array}$ & & & \\
\hline (corra & litos Serie & & & & \\
\hline Nov. & $\begin{array}{l}19 \\
23 \\
23\end{array}$ & $\begin{array}{lll}02 & 46 & 41.7 \\
02 & 55 & 40.5 \\
05 & 09 & 13.6 \\
20 & 47 & 40.1 \\
09 & 05 & 08.0\end{array}$ & $\begin{array}{r}37^{0}\left(03.3^{\prime}\right. \\
0.3 .9 \\
03.8 \\
02,3 \\
02.4\end{array}$ & $\begin{array}{c}121+1.5^{\prime} \\
40.5 \\
40.3 \\
42.1 \\
42.9\end{array}$ & $\begin{array}{l}5.0 \\
2.7 \\
2.5 \\
3.2 \\
3.5\end{array}$ \\
\hline Jan. & $\frac{2}{7}$ & $\begin{array}{lll}09 & 56 & 51.3 \\
09 & 58 & 59.7 \\
10 & 47 & 36.5 \\
12 & 16 & 32.0 \\
00 & 50 & 01.2 \\
02 & 59 & 37.1 \\
03 & 00 & 03.9\end{array}$ & $\begin{array}{c}366^{\circ} 50.55^{\prime} \\
49.3 \\
51.5 \\
49.6 \\
50.8 \\
49.3 \\
50.6\end{array}$ & $\begin{array}{c}12139.3 \\
39.6 \\
37.8 \\
41.8 \\
38.5 \\
42.7 \\
37.7\end{array}$ & $\begin{array}{l}3.5 \\
2.6 \\
2.7 \\
3.1 \\
2.8 \\
2.7 \\
2.9\end{array}$ \\
\hline$(S e n F$ & rlipe lake & & & & \\
\hline Jau. & $\begin{array}{ll}3 & 1966 \\
5 & \\
9 & \\
14 \\
17\end{array}$ & $\begin{array}{lll}15 & 38 & 38.6 \\
05 & 55 & 06.4 \\
00 & 03 & 20.6 \\
00 & 08 & 00.9 \\
00 & 30 & 12.0 \\
00 & 40 & 08.1 \\
01 & 48 & 08.1 \\
02 & 03 & 20.0 \\
02 & 23 & 37.3 \\
02 & 48 & 37.6 \\
06 & 22 & 56.5 \\
10 & 36 & 17 \\
15 & 04 & 48.8 \\
19 & 51 & 15.7 \\
20 & 02 & 34.3 \\
04 & 10 & 36.0\end{array}$ & $\begin{array}{r}36 \% 58 \\
59 \\
58 \\
58 \\
58 \\
59 \\
59 \\
59 \\
37^{\circ 000} \\
00 \\
00 \\
36058 \\
58 \\
58 \\
59\end{array}$ & $\begin{array}{r}121028 \\
28 \\
28 \\
28 \\
29 \\
29 \\
29 \\
29 \\
28 \\
30 \\
30 \\
27 \\
29 \\
29 \\
28\end{array}$ & $\begin{array}{l}2.2 \\
2.9 \\
2.5 \\
3.3 \\
2.6 \\
3.3 \\
4.1 \\
3.1 \\
3.0 \\
2.8 \\
2.6 \\
2.4 \\
2.4 \\
2.7 \\
3.5\end{array}$ \\
\hline
\end{tabular}

The fourth sequence occurred on January 1966. The shocks are clustered in a small area near San Felipe lake. The spatial distribution of the sequence is then, of the same type as that of the Corralitos series, but they differ in the distribution of the magnitudes of the shocks with time. The largest shock, $M=4.1$, occurred not at the beginning, but at the middle of the series. The sequence was started with an increase of seismic activity at the $M=2.5$ level on January 3 . 
On January 17 occurred the main shock of the series, which was followed by 8 shocks of $M>2.2$ in a 4 day period. Because of the concentrated location of the epicenters it is difficult to separate the first

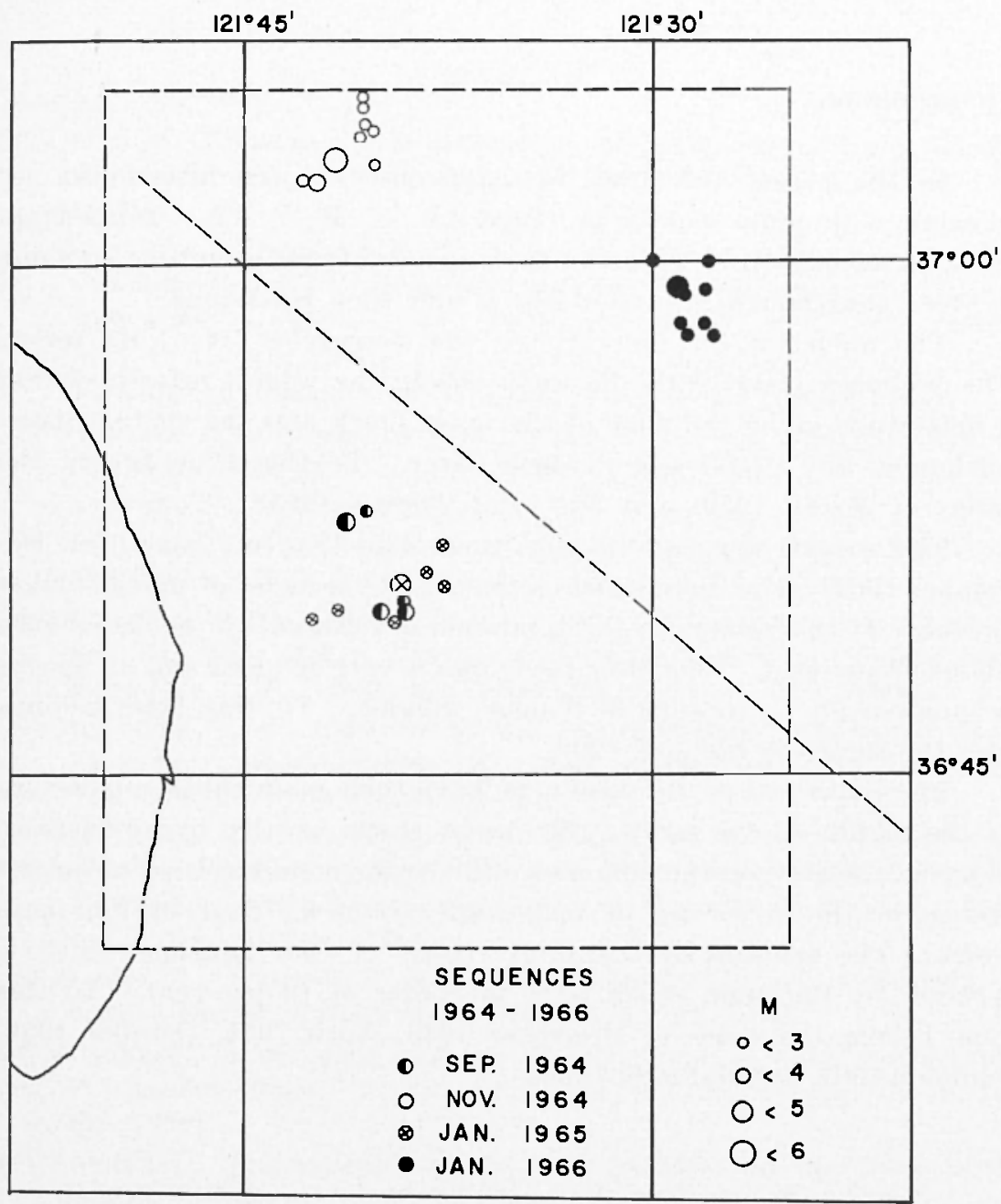

Fig. 16 - Epicenter location of the sequences of the period 1964-1966.

part of the activity from that following the main shock. In the Corralitos series the members of the sequence have small magnitudes compared with that of the main shock, so that the energy released by the main shock represents about 98 per cent of that of the total 
series. In the San Felipe, lake series the energy was released over a period of 18 days in small increments. The energy of the main shock represents only i2 per cent of the total.

\section{CoNctusions.}

In the period 1953-1966 we have observed ten aftershocks sequences with main shocks in range $4.0<M<$ 6.0. Tentatively these series have been group in three general types according to some of their characteristics in the spatial and time behaviour.

The model of the first type is the September 1t, 1963 series. The sequence starts with the main shock, the largest aftershock has a magnitude about 0.8 that of the main shock and the spatial distribution of the aftershocks in quite large. To this type belong the series of March 1959, and May and August 1963.

The second type groups sequences like that of Cormalitos, November 1964. The main shock is followed by a series of much smaller shocks. It contributes to the total energy released by the series with about 98 per cent. The aftershock area is very reduced and all shocks originate from a considerably small volume. To this type belongs also the series of January 1960.

The sequences of the third trpe have their main shock somewhere at the middle of the series. The series starts usually by an increase of seismic activity in the area above the background level. The largest shocks in the series are of magnitude about 0.9 that of the main shock. The fraction of the total energy of the sequence which is released by the main shock is of the order of to ver cent. To this type belong the series of December 1953, April 1954, October 1956, January 1961, and January 1966.

\section{ACKNowlangenents.}

The above work was done while the anthor was visiting resenreh seismologist at the Seismographic Station, Department of Geology and Geophysics, University of California, Berkeley. He would like to acknowledge Dr. Bruce Bolt and the staft for the help afforded him. 
The research was carried out under Contract $A F+9$ (638)-904 of the Dir Force Office of Scientific Research as part of the Vela Tinform program.

\section{REFERENCES}

(1) B.RTi VI.. Richter C., Vechanism of the aflershoeks of hern Counly, California earlhqualie of 19.j:. "Bull. Seism. Soc. Am.", 48, 133-1+6. (1958).

(2) Bol.t B. A., TuncotTe F. T.. Compuler locations of local earlhquakes within the Berkeley Scismographie Velworl. "Computers in the Mincral Industries". Stanford Vniv. Publ. (ieol. Sci. 9, 2, 561-576, (1963).

(3) Buxz V. I., Melhods for a delailed sludy of seismicily. Eal. by Yu. V. Riznichenko. Jzdatel'st vo Akademii Nauk SSSR, Moskva (1960).

(') Jexwisas C. W., SthaxD R. (G., Santa Cruz shed, Geologie Map of (aliformia. Olaf P. Jenkins Edition; Calif. Division of Miness and Geologry, I: 250,000). (1958).

(5) McEvilas T. Y., Earlhqualie sequence of Nor. 196-l near corralilos. California. "Bull. Seism. Soce. Am.", 56, 755-773, (1966).

(') McEviluy T. V., Parkfield earthquakes of Jume 2z-29, 1966, Monterey and San Luis Obispo Counlies, California: Preliminary scismic dala, June-July 1966i. "Bull. Seism. Soc. Am.", 56, 967.971. (19666).

(7) McEvilur T. Y., Casaday K. B., The Earlhquelie Sequence of Sept. 1965, near Antioch, Califormia. "Bull. Seism. Soc. Am.", 57, 113 124. $(1967)$.

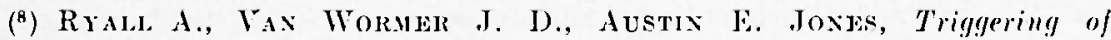
Microearthauakes by Earth lides, and other fealures of the Truckee. Califormia, earlhquake sequence of september, 196t; "Bull. Seism. Soce. An. ", 58, 215-248, (1968).

(") Suzuki 7., A statistical sludy of the occurrence of small earlhqualies. I. sience Report. Toholu liniv. Series 5, 5, 177, (1935).

(10) Suzuki \%., A statistical study of the occurrence of small earlhqualess. IV. Science Report, Toloku Univ., Series 5. in "Geophys.", 11, 10. $54,(1958)$.

(11) Tocuen 1)., Seismographic results from the 19:50 San Francisco earlhquakes. (alifornia Division of Mines special Report 57 (1959).

(12) Unias A., A study of the aftershorlss and focal mechanism of the Salinas. Walsomville earliquales of Augusl 31 and seplember 14, 1963. " Bull. Seism. Soc. Am. $"$, 55. 85-106, (1965).

(13) U's'su 'T., Statistical shudy on the occurrence of aflershocks. " Geophys. Mag. ", 30, 521-605), (1960). 